\title{
Managing Rather Than Avoiding "Difficulties" in Building Landscape Resilience
}

\author{
Hongzhang $X u^{1,2, *}$, Meng Peng ${ }^{3,+}$, Jamie Pittock $^{1}$ and Jiayu $\mathrm{Xu}^{3, *}$ \\ 1 Fenner School of Environment and Society (Bld 48), The Australian National University, \\ Canberra, ACT 2601, Australia; jamie.pittock@anu.edu.au \\ 2 Australian Centre on China in the Wold, The Aurtralia National University, Canberra, ACT 2601, Australia \\ 3 School of Environment, Tsinghua University, Beijing 100083, China; mvponesky@mail.tsinghua.edu.cn \\ * Correspondence: hongzhang.xu@anu.edu.au (H.X.); jiayu-xu@tsinghua.edu.cn (J.X.) \\ + Co-First Author: Meng Peng.
}

Citation: Xu, H.; Peng, M.; Pittock, J.; $\mathrm{Xu}, \mathrm{J}$. Managing Rather Than Avoiding "Difficulties" in Building Landscape Resilience. Sustainability 2021, 13, 2629. https://doi.org/ $10.3390 /$ su13052629

Academic Editors: Oliver Frör,

Elisabeth Berger and

Daniel Callo-Concha

Received: 20 January 2021

Accepted: 23 February 2021

Published: 1 March 2021

Publisher's Note: MDPI stays neutral with regard to jurisdictional claims in published maps and institutional affiliations.

Copyright: (c) 2021 by the authors. Licensee MDPI, Basel, Switzerland. This article is an open access article distributed under the terms and conditions of the Creative Commons Attribution (CC BY) license (https:/ / creativecommons.org/licenses/by/ $4.0 /)$.

\begin{abstract}
Building landscape resilience inspires the cultivation of the landscape's capacity to recover from disruption and live with changes and uncertainties. However, integrating ecosystem and society within such a unified lens-that is, socio-ecological system (SES) resilience-clashes with many cornerstone concepts in social science, such as power, democracy, rights, and culture. In short, a landscape cannot provide the same values to everyone. However, can building landscape resilience be an effective and just environmental management strategy? Research on this question is limited. A scoping literature review was conducted first to synthesise and map landscape management change based on 111,653 records. Then, we used the Nuozhadu (NZD) catchment as a case study to validate our findings from the literature. We summarised current critiques and created a framework including seven normative categories, or common difficulties, namely resilience for "whom", "what", "when", "where", "why", as well as "can" and "how" we apply resilience normatively. We found that these difficulties are overlooked and avoided despite their instructive roles to achieve just landscape management more transparently. Without clear targets and boundaries in building resilience, we found that some groups consume resources and services at the expense of others. The NZD case demonstrates that a strategy of building the NZD's resilience has improved the conservation of the NZD's forest ecosystems but overlooked trade-offs between sustaining people and the environment, and between sustainable development for people at different scales. Future researchers, managers, and decision-makers are thereby needed to think resilience more normatively and address the questions in the "seven difficulties" framework before intervening to build landscape resilience.
\end{abstract}

Keywords: critiques; framework; justice; landscape; resilience; socio-ecological systems

\section{Introduction}

The relationship between ecological conservation and the livelihood of people who make a living on natural resources is of crucial concern to conserving biodiversity, reducing carbon emissions, reducing poverty, and promoting sustainable development $[1,2]$. Society's demands on the environment are increasingly changing and diversifying, and this means that stakeholders now expect a landscape to concurrently fulfil more biophysical and sociocultural functions [3-5]. Landscapes reflect the relationship between human society and natural environment [6,7]. In facing a rapidly changing world, building resilience $[8,9]$ has been proposed to guide environmental management to deal with risks, such as the effects of climate change [10-12]. Building resilience can enhance a landscape's ability to meet the needs of people, plants, animals, and microorganisms among others [13-16]. Moreover, many scholars suggest managing landscapes for resilience to adapt, recover, or reorganise while facing disturbances $[8,17,18]$. "Although landscapes will persist in some form, it is unlikely that they will provide the same values to people or habitat for wildlife" (p. 1047) [19], or to every person [20]. Thus, here we ask: Is building landscape resilience 
an effective and just management strategy for meeting and coordinating the competing needs of different actors who are dependent on the landscape? In addition, what are the common "difficulties" that should be dealt with by applying this notion in management?

To identify potential conflicts and instruct management, these two research questions need to be asked by researchers, managers and decision-makers before approaching the task of building landscape resilience. A landscape cannot provide the same values to all stakeholders and the prognosis of risks and challenges is also essential as identification or opportunities and benefits [21]. Considering the urgency and need to incorporate resilience into management normatively, we reviewed 111,653 publications on landscape management and summarised the research trends in this area. Building on this discourse, we defined a "seven difficulties framework" and proposed that this framework should be used as a checklist before applying the concept of resilience to the just and sustainable management of landscapes. Then, we exemplified these common difficulties based on our study of the management of the Nuozhadu (NZD) catchment, upper Mekong river. We conclude the paper by highlighting the need to justly and sustainably manage competing landscape needs, goals, and priorities of different actors while conserving the environment.

\section{Literature Review}

\subsection{Review Approaches}

A systematic review was initially developed in healthcare in the 1970s and has become a recognised standard for accessing, appraising and synthesising evidence, and has gradually been used in other disciplines [22-24]. Here, a literature review was undertaken, applying the methodological framework (Table 1) of Arksey and O'Malley [25] to understand trends in research for sustainable landscape management.

Table 1. Literature review methods adapted from Arksey and O'Malley [25].

\section{Methodological Framework of Scoping Studies (Arksey and O'Malley, 2005)}

1. Identifying the research question

2. Identifying relevant studies
Clearly articulate the research question based on research goals. Consider the population, intervention and outcomes of interest to establish an effective search strategy.

Choose bibliographic databases, web-based search engines (e.g., Google Scholar) or grey literature source (e.g., organisation websites and thesis repositories).

\section{Implementation}

Goal: Understand the landscape of the underpinned scientific world of sustainable landscape management and the philosophy behind.

Research question: What is known in the existing literature about sustainable (outcome) management (intervention) of landscape (population)? Web of Science (WoS) Core Collection (1900-present) including:

- $\quad$ Science Citation Index Expanded (SCI-EXPANDED)-1900-present;

- Social Sciences Citation Index (SSCI)-1900-present;

- $\quad$ Arts \& Humanities Citation Index (A\&HCI)-1975-present;

- Conference Proceedings Citation Index-Science (CPCI-S)-1990-present;

- Conference Proceedings Citation Index-Social Science \& Humanities (CPCI-SSH)-1990-present;

- $\quad$ Emerging Sources Citation Index (ESCI)-2015-present;

- Current Chemical Reactions (CCR-EXPANDED)-1985-present;

- Index Chemicus (IC)_1993-present. 
Table 1. Cont

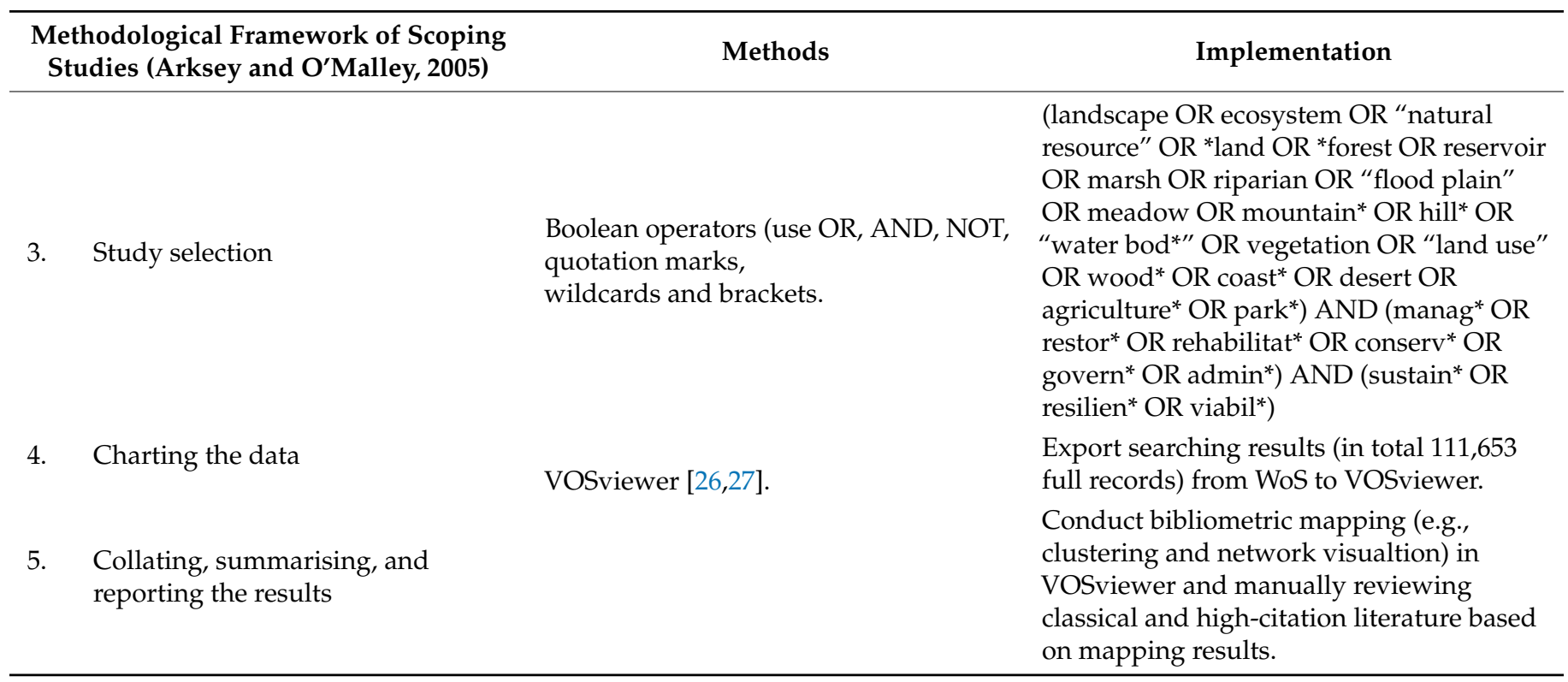

To assess the trends in research for sustainable landscape management, we used the VOSviewer developed by Van Eck and Waltman [26] to synthesise and map the change of keywords of 111,653 records (Figure 1) from the Web of Science (WoS) Core Collection from 1988 to 2018 (Figure 2).

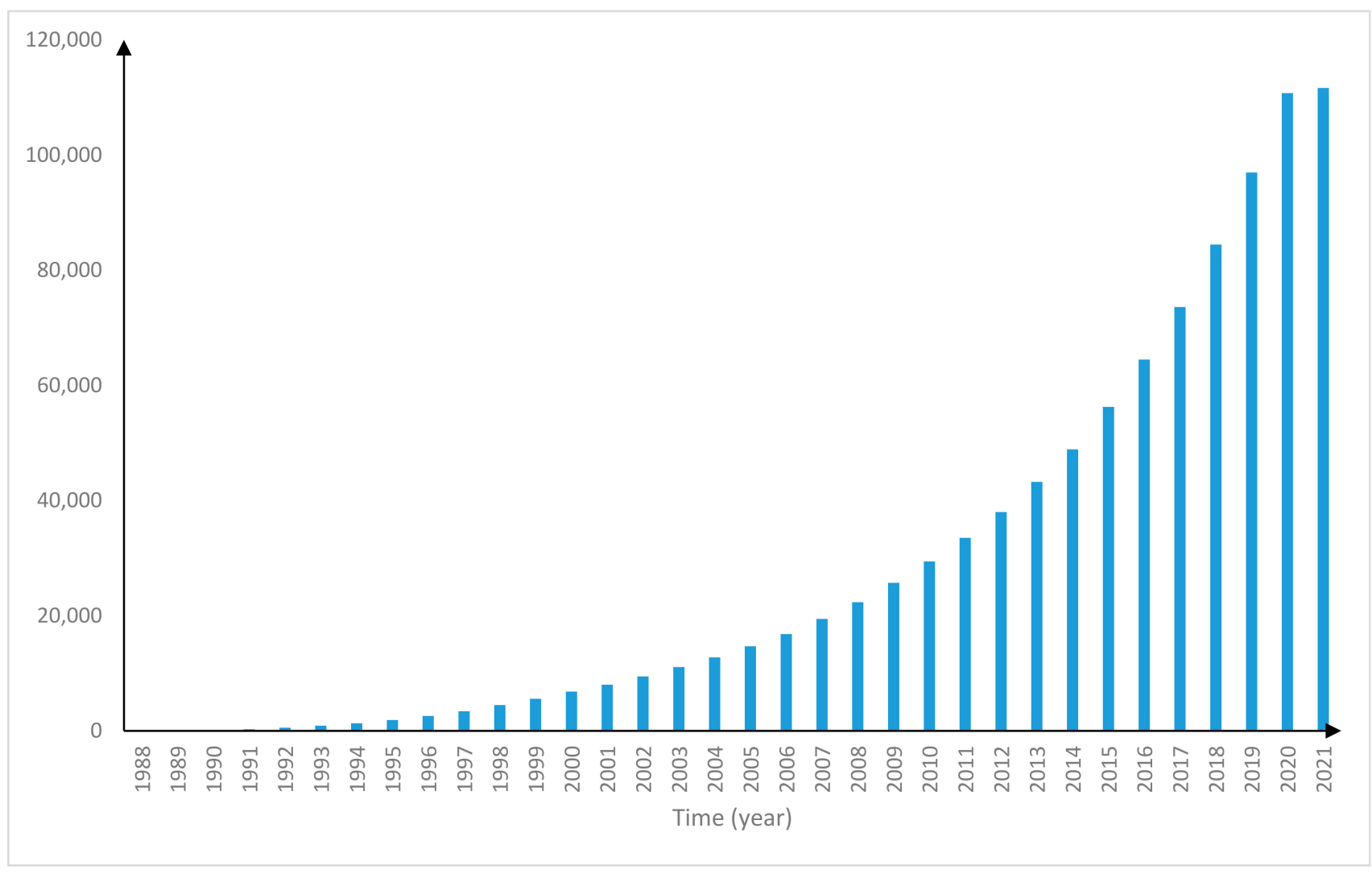

Figure 1. Cumulative number of publications on sustainable landscape management accessed by the Web of Science from 1998 to 2021. 


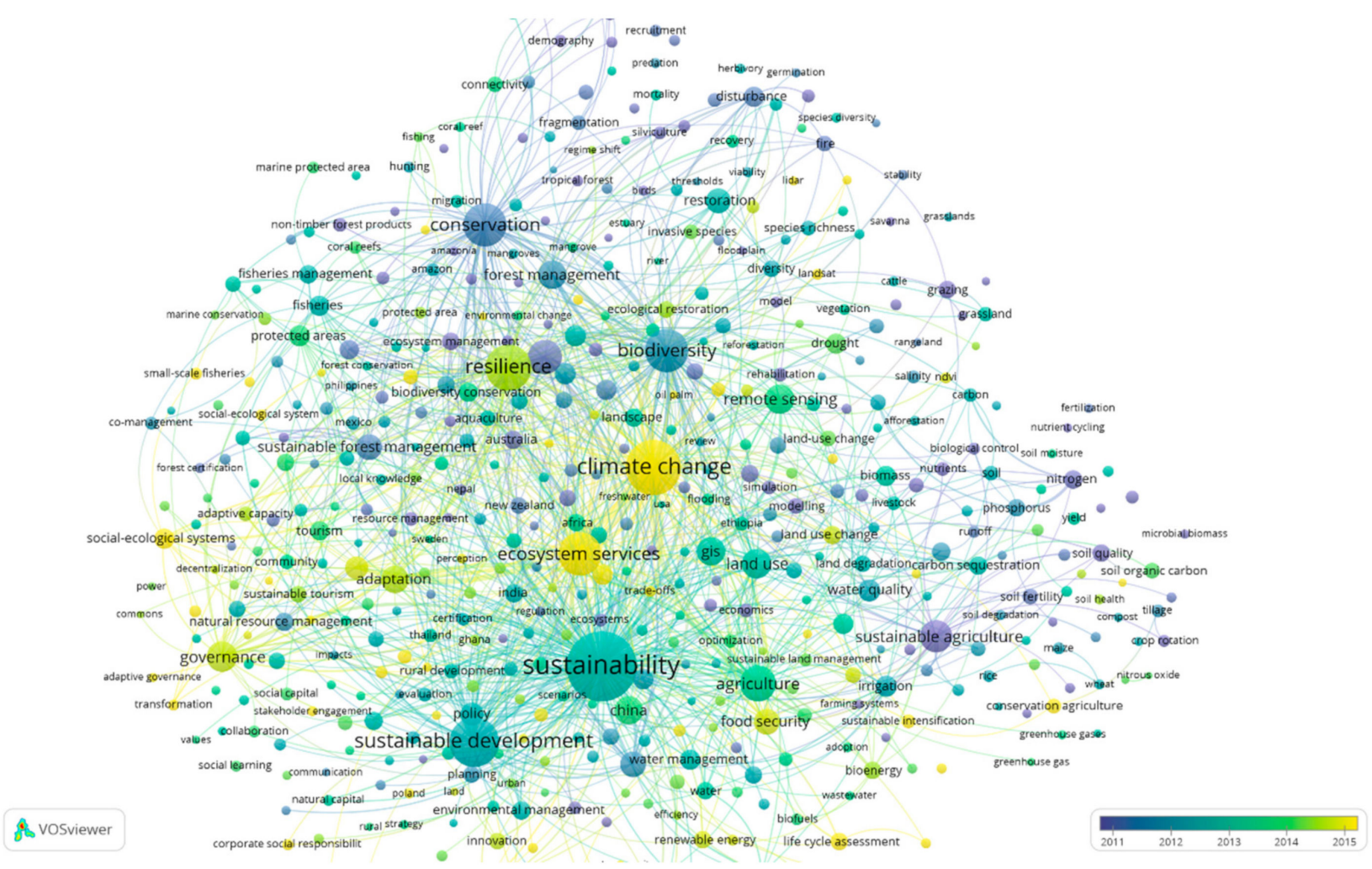

Figure 2. Literature mapping of key terms used in publications on sustainable landscape management accessed by the Web of Science from 1998 to 2018, via VOSview.

\subsection{Landscape Approaches, Socio-Ecological Systems and Resilience}

Landscape approaches that integrate social and ecological systems [28] as socioecological systems (SESs) have attracted an increasing amount of research [29-31]. The strategies and knowledge of landscape management have been challenged by changing expectations for how the land and resources should be managed. This is exemplified by the change of keywords used in publications from conservation and biodiversity (in blue) to sustainability and sustainable development (in green), and resilience and climate change (in yellow) (Figure 2). From the nineteenth century, the approaches to landscape management were to identify ways of solving problems for the traditional utilisation including agricultural production and timber harvesting. The approach was to sustain the natural system's capability to provide the desired products and services [32]. Most prevailing studies at this stage talked about restoration, conservation-based management, and strategies such as the conservation of water and biological diversity [33]; maintenance of soil quality and fertility [34]; prevention of soil erosion [35]; sustainable crop production [36,37]; and forest management, habitat maintenance, and rehabilitation [38,39]. After the Rio Earth Summit in 1992 [40] and the release of the Millennium Ecosystem Assessment [41], an increasing number of studies began to challenge the traditional problem-solving approach. These studies proposed that the purpose of sustainable landscape management is to use ecosystems sustainably and in ways that contribute to human well-being [3,42]. Since the 2000s, more studies have recognised the challenges of living in an increasingly unstable and complex world undergoing global environmental change (e.g., climate, technological, and political change) [42]. These studies challenge the prevailing sustainable exploitation-based strategy which tries to identify and manage an "optimal" point between human needs and the conservation of the environment [43-46]. Integrative and holistic approaches, such as systems thinking, try to provide tools for managers to steer development and stewardship processes towards the desired states $[47,48]$. 
An SES is also called a human-nature or human-environment system, and it is a perpetually dynamic and complex system with the continuous interactions of many subsystems, such as a resource system, resource units, governance system, and users [49-51]. Although the notion of SESs was coined in 1970 [52], it was first transformed into a framework by Berkes et al. [53] around 20 years later [54]. Moreover, its first application by Berkes et al. [53] emphasised the significance of building resilience in natural resource management. Resilience is the ability to adapt, change, and reorganise while coping with disturbance and meeting shocks [55], and building the resilience of SESs to all kinds of disturbance and threats has become a pursuit of many plans and practices of management schemes [56,57].

Thinking of the earth system as dynamic and complex [58], the SES concept has had wide influence, including in finance (e.g., attracting investment in natural capital), policy (e.g., policy design, implementation, and monitoring), governance systems (e.g., trade-offs between conservation and development) [50], and in other fields such as arts, humanities, medicine, and psychology [54]. Furthermore, several frameworks [50,59-61] and conceptual models $[62,63]$ have been developed and applied to SESs to facilitate better policy design and practical management (e.g., urban planning and sustainable agriculture) [59,64-66]. Thus, we argue that sustainable landscape management should not favour either ecology or people under the SES concept. It should seek to avoid irrecoverable damage to an ecosystem's resilience or a human population's sustainable livelihoods, which is especially crucial when a population's livelihoods or well-being is closely connected to an ecosystem and natural resources $[7,41,67,68]$. Thus, building all parts of landscape resilience, that is the ability to adapt, change, and reorganise while coping with disturbance and meeting shocks, is increasingly important for a just and sustainable world [55,69-71].

The concept of building systems' resilience inspires the cultivation of the systems' capacity to recover from disruption and live with changes and uncertainties, and in doing so, challenges traditional or dominant management schemes [21]. However, many scholars find that integrating ecosystem and society within such a unified lens-that is, building resilience for the whole SES - clashes with a range of cornerstone concepts in social science for politics and governance in human society, such as power, democracy, rights, and culture (Klein et al., 2004, Davoudi et al., 2012, Fabinyi et al., 2014, Meerow and Newell, 2019). Building resilience in all parts of the SESs rather than to particular threats has been one of the main approaches proposed by resilience scholars (Olsson et al., 2014, Walker, 2020). However, this idealistic approach is very difficult to implement in practice, as building the resilience of some groups to certain threats will unavoidably detract from the interests of other groups [21,72-76]. For instance, in managing rivers, different stakeholders compete for conflicting ecosystem services such as fish versus hydroelectricity $[77,78]$. From a basin perspective, building dams could strengthen the resilience of the local community toward water security, flood mitigation, and affordable energy [78], but would reduce lower-reach communities' food security due to the loss of fish production [79]. From a multi-scale perspective, building dams could increase the global communities' resilience to climate change by reducing carbon emissions [78], but it may also reduce local communities' incomes and food supply [80,81]. Thus, if resilience is improved for all parts of the SESs, trade-offs need to be considered to meet the competing needs of different people at different scales. The kinds of perverse impacts that may be triggered in building resilience, defined as the seven difficulties, are now considered.

\section{The Seven Difficulties Framework}

The fields of science and social science are increasingly demanding the development of better practices for resilience thinking. Some interdisciplinary groups of researchers, such as the Santa Fe Institute and the Resilience Alliance, have developed frameworks and workbooks to translate this thinking into practice [82,83]. Moreover, some natural source management organisations, such as the Goulburn Broken Catchment Management Authority in Australia, have engaged local communities and developed their management 
strategies based on resilience thinking [84], and thinkers have also proposed a range of different methods for assessing and measuring resilience and its changes [84,85]. A milestone is the resilience assessment workbook by Resilience Alliance [86] that uses an issue-based approach and provides worksheets to guide the assessment of resilience $[85,86]$.

However, resilience thinking has also been criticised for the inadequate consideration of peoples' rights, governance, power, and cultural issues [73-91]. Critics argue that resilience thinking grows out of the complex systems theory of Holling [69], depoliticises changes (i.e., shock and disturbance), and overemphasises a unified and scientific approach of "imposed rationality" that is alien to the practices of human societies [74,92-95]. Table 3 summarises current critiques of resilience thinking into seven normative categories, or common difficulties, namely resilience for "whom", "what", "when", "where", "why", as well as "can" and "how" we apply resilience normatively.

Table 2. Seven categories of common "difficulties" in building resilience. Source: Author.

\begin{tabular}{|c|c|c|}
\hline Seven Categories of Typical Difficulties & Critiques & Representative Literature \\
\hline \multirow{6}{*}{$\begin{array}{c}\text { Whom? } \\
\text { Setting subjects for resilience: Different } \\
\text { actors value different resilience differently }\end{array}$} & Who desires the current resilience system? & {$[21,72,73,89]$} \\
\hline & $\begin{array}{l}\text { Whose resilience is prioritised? For example, the } \\
\text { resilience of some groups is achieved at the } \\
\text { expense of certain other social groups and } \\
\text { regions that bear the costs for resistance, } \\
\text { adaptation, restructuring or transformation. }\end{array}$ & {$[16,73,74,89,96]$} \\
\hline & Who determines what is desirable? & {$[16,19,21,73,74,89,91,93,97]$} \\
\hline & Who is included, and who is excluded? & {$[16,21,74]$} \\
\hline & $\begin{array}{l}\text { Some regimes are undesirable by most people } \\
\text { but super resilient, e.g., harsh dictatorships, } \\
\text { salinized regions, and psychotic states in people. }\end{array}$ & {$[21,43,55,73,89,97,98]$} \\
\hline & Who is responsible for building resilience? & {$[21,74,91,96,99]$} \\
\hline \multirow{8}{*}{$\begin{array}{c}\text { What? } \\
\text { Setting objects for resilience: Resilience } \\
\text { of/from what, to what }\end{array}$} & $\begin{array}{c}\text { Unclear meaning of resilience, e.g., three } \\
\text { dimensions of resilience as conflicting with each } \\
\text { other: resistance vs. adaptivity vs. } \\
\text { transformability. }\end{array}$ & {$[73,74]$} \\
\hline & Unclear meaning of equilibrium. & {$[72,92,100]$} \\
\hline & $\begin{array}{l}\text { An "umbrella concept" not being operational to } \\
\text { support planning or management. }\end{array}$ & {$[72,74,92]$} \\
\hline & To what extent of management. & {$[43,72]$} \\
\hline & $\begin{array}{c}\text { From what? What is the standing point: human } \\
\text { society as part of nature OR social domain } \\
\text { extending to nature. }\end{array}$ & {$[74,87,91]$} \\
\hline & $\begin{array}{l}\text { What is the main driver of change or collapses? } \\
\text { Predictable or not? }\end{array}$ & [87-89] \\
\hline & $\begin{array}{l}\text { What is our greatest asset? Human agency, } \\
\text { including knowledge and institutions, or nature? }\end{array}$ & {$[88,89,94]$} \\
\hline & $\begin{array}{l}\text { What mediates human-environment relations } \\
\text { (or is there a need)? }\end{array}$ & {$[89,94]$} \\
\hline \multirow{2}{*}{$\begin{array}{l}\text { When? } \\
\text { Setting time scale for resilience }\end{array}$} & $\begin{array}{l}\text { Is the focus on short-term, e.g., current } \\
\text { generation and rapid onset or long term, e.g., } \\
\text { future generation and cumulative resilience? }\end{array}$ & [16] \\
\hline & $\begin{array}{l}\text { Resilience from when, e.g., } 1000 \text { years ago or } 10 \\
\text { years ago to when, e.g., now or future? The } \\
\text { action taken now to build stability may reduce } \\
\text { adaptive capacity to future changes. }\end{array}$ & [89] \\
\hline
\end{tabular}


Table 3. Seven categories of common "difficulties" in building resilience. Source: Author.

\begin{tabular}{|c|c|c|}
\hline Seven Categories of Typical Difficulties & Critiques & Representative Literature \\
\hline \multirow{3}{*}{$\begin{array}{c}\text { Where? } \\
\text { Setting boundaries for resilience }\end{array}$} & $\begin{array}{l}\text { The unclear boundary } \\
\text { between nature and society. }\end{array}$ & {$[74,87,93]$} \\
\hline & $\begin{array}{l}\text { The unclear boundary of different scales, i.e., } \\
\text { current-smaller-larger. For example, } \\
\text { geographically, local, city-level, provincial, } \\
\text { national or global scales? }\end{array}$ & [74] \\
\hline & $\begin{array}{l}\text { Blurring boundaries between crisis response and } \\
\text { daily management. }\end{array}$ & {$[43,91]$} \\
\hline \multirow[b]{2}{*}{$\begin{array}{c}\text { Why? } \\
\text { Explicitly stating the motivations }\end{array}$} & What is the goal of building resilience? & {$[16,21]$} \\
\hline & $\begin{array}{l}\text { Is resilience a good characteristic all the time? } \\
\text { What are the underlying motivations for } \\
\text { building resilience? }\end{array}$ & {$[16,21,73]$} \\
\hline $\begin{array}{c}\text { How? } \\
\text { A clear and transparent plan is needed }\end{array}$ & $\begin{array}{l}\text { Lacking clear guidance as to how resilience can } \\
\text { be improved-are there any measurable goals? }\end{array}$ & {$[72,90]$} \\
\hline \multirow{7}{*}{$\begin{array}{c}\text { Can? } \\
\text { Examining assumptions }\end{array}$} & $\begin{array}{l}\text { Can organisations and institutions } \\
\text { learn as individuals do? }\end{array}$ & {$[73,87]$} \\
\hline & $\begin{array}{l}\text { Can social and ecological systems be unified } \\
\text { under the same terms/principles, or common } \\
\text { theorisation of dynamics? For example, "the } \\
\text { 'well-being' of the social system is simply an } \\
\text { impossible phrase" (Hornborg, 2009: 254). }\end{array}$ & {$[43,73,87,89]$} \\
\hline & $\begin{array}{l}\text { Can higher diversity and connectivity equal to } \\
\text { higher resilient or buffering capacity? }\end{array}$ & [88] \\
\hline & $\begin{array}{l}\text { Can people's interests and livelihoods be defined } \\
\text { as primarily concerned with nature? }\end{array}$ & [101] \\
\hline & $\begin{array}{l}\text { Can the concept of resilience be used to include } \\
\text { all responses to disturbance? }\end{array}$ & {$[73,74,88,97]$} \\
\hline & $\begin{array}{l}\text { Can knowledge be captured and } \\
\text { stored as a "thing" or a "process"? }\end{array}$ & [89] \\
\hline & Can resilience be used as a normative concept? & [102] \\
\hline
\end{tabular}

These critiques show that building resilience without clear targets and boundaries could have perverse outcomes. Resilience is "two-faced" and is neither good nor bad [55,73]. A system can be ecologically resilient but not socially desirable, and vice versa $[21,103,104]$. Resilience thinking fits with the complex systems theory within neoliberalism (or postliberalism) $[43,74,99,105]$, which evolves from critiques of libertarians, environmentalists and leftists to a homogenising philosophy of top-down natural resource management and a desire of holism since the Cold War [106,107]. Epistemological traditions of complex systems theory are based on a non-linear, dynamic, tipping-points and stochastic ontology $[92,108,109]$. These often depoliticise causal processes but emphasise self-reliant individuals and the harmonious functioning of natural systems through adaptation, wise management and appropriate technologies $[43,88,101,110]$. In addition, an idea of building resilience of SESs is cognate to pre-modern cosmologies that is somewhat in favour of the "savage thought' of Lévi-Strauss [53,87,110].

Building systems for an increasingly complex world with rising unpredictable changes has been proposed in strategies and plans under the resilience paradigm [55,111]. However, many on-the-ground practices mitigate against a sophisticated resilience response. These strategies and plans have often been reduced to emergency responses that emphasise short-term damage reduction $[55,74]$. Thus, our society could be misled into new dead ends, either to "rigidity traps" of harsh dictatorship like the totalitarian socialism of 
the Soviet Union that is very internally resilient [106] or to the individual or community self-governance by diminishing the responsibility of the government [91]. With extreme self-governance, local landscape use may detract from the interests of the broader society and not address the normative questions we listed in the seven difficulties framework, such as resilience of what and for whom [90]. For example, the transitions towns movement established in the United Kingdom in 2005 initially aimed to build local communities' resilience to threats such as climate change, peak oil, and global financial crises by empowering people at the grassroots, restructuring social services, and reducing reliance on formal government [90]. This is done through the process of building community resilience by reinforcing autonomous activism or self-governance, that is, localising social, political, and economic interdependencies $[91,97,112]$. However, weakening formal governments will not always provide favourable outcomes because it could also reduce capacities to sustain public safety, such as reductions in police and fire services, and worsen inequalities between wealthier and poorer districts by reducing central coordination and cross-subsidies [113]. Thus, a paradoxical phenomenon will be triggered, that is, "decentralise power in the community, resulting in local residents taking action towards their own future post-disaster, while simultaneously seeking to hold government and other centralised power structures to account" (p.28) [97].

Based on this philosophical premise, by unifying nature and society under a single set of all-encompassing principles, resilience thinking has adopted a single epistemology of complex system theory [107]. Resilience thinking focusses on "unknown unknowns" (e.g., frequency, intensity, and timing of what disasters) and "unknown knows" (e.g., marginalised knowledge) but overlooks "known knows" (e.g., power and culture matter for human-environment relations) and "known unknowns" (e.g., where to look for a comprehensive and perfect dataset for decision making) of human society [101]. Resilience thinking emphasises managing uncertainties but current governance systems have also always operated under uncertainties and surprises, because policies are always made with a deficit of information and unpredictability [114]. Embedding resilience thinking into governance systems or embedding governance systems into resilience thinking to deal with complexity has been a topic of debate [92]. Critics of resilience thinking say that it overlooks opportunities to consider essential issues such as powers, rights, and conflicts, assumes that we are in a complex world where the only certainty is uncertainty [91], and thereby relies on self-management or self-governance solutions $[110,115]$. However, these critiques are not sufficient to deny the effectiveness of building a resilient system if adequate responses could be incorporated into management. We argue for a process of incorporating responses to the seven difficulties in planning to build resilient systems such as landscapes. In the following section, we use the Nuozhadu (NZD) catchment landscape as an example to show the importance of failing to consider these difficulties in building resilience.

\section{An Example of Difficulties in Building Resilience: The Nuozhadu (NZD) Catchment Landscape}

4.1. Background

Conflicts between the conservation of the environment and human well-being have long been discussed with respect to dams and reservoirs [41,116,117]. As a large source of renewable energy and flexible supply, hydropower has a major role in reducing global carbon dioxide emission. Nevertheless, hydropower also has severe negative impacts on ecology and society [118]. Sustainable catchment management is needed to mitigate its impacts on ecosystems (e.g., freshwater biodiversity) and the people affected by it, such as resettlers [119-123]. The sustainable management of landscapes affected by the construction of large reservoirs is important for biodiversity conservation and the livelihoods of resettlers [124-126]. Experiences with catchment management provide lessons for the integrated and sustainable management of other types of landscapes across the globe.

The Lancang-Mekong River is the ninth longest river in the world and the fifth longest in Asia. The river originates from the Jifu Mountain in the western part of the Qinghai-Tibet Plateau and flows southwards into the South China Sea [77]. As the largest hydropower 
station (23.703TL; $5.85 \times 10^{6} \mathrm{~kW} ; 261.5 \mathrm{~m}$ ) on the Lancang River (i.e., upper Mekong River), the construction of the NZD Dam and its affiliated projects such as highways and bridges triggered significant resettlement. More than 46,000 people were relocated, $57 \%$ of the people resettled from all of the dams constructed on the Lancang River (Figure 3) [127]. More broadly, over 407,300 people were affected by the NZD. These people were resettled across nine counties, 110 townships, 1022 villages, and 15,051 village groups [128]. Around $95 \%$ of the people relocated by the NZD project were peasants with agricultural livelihoods. Among the 29,737 hectares of land inundated, more than 27,742 hectares (93.3\%) were agricultural, in which 5816 hectares were cultivated, 2614 were vegetable gardens, 17,994 were forests, and 622 were meadows [128].

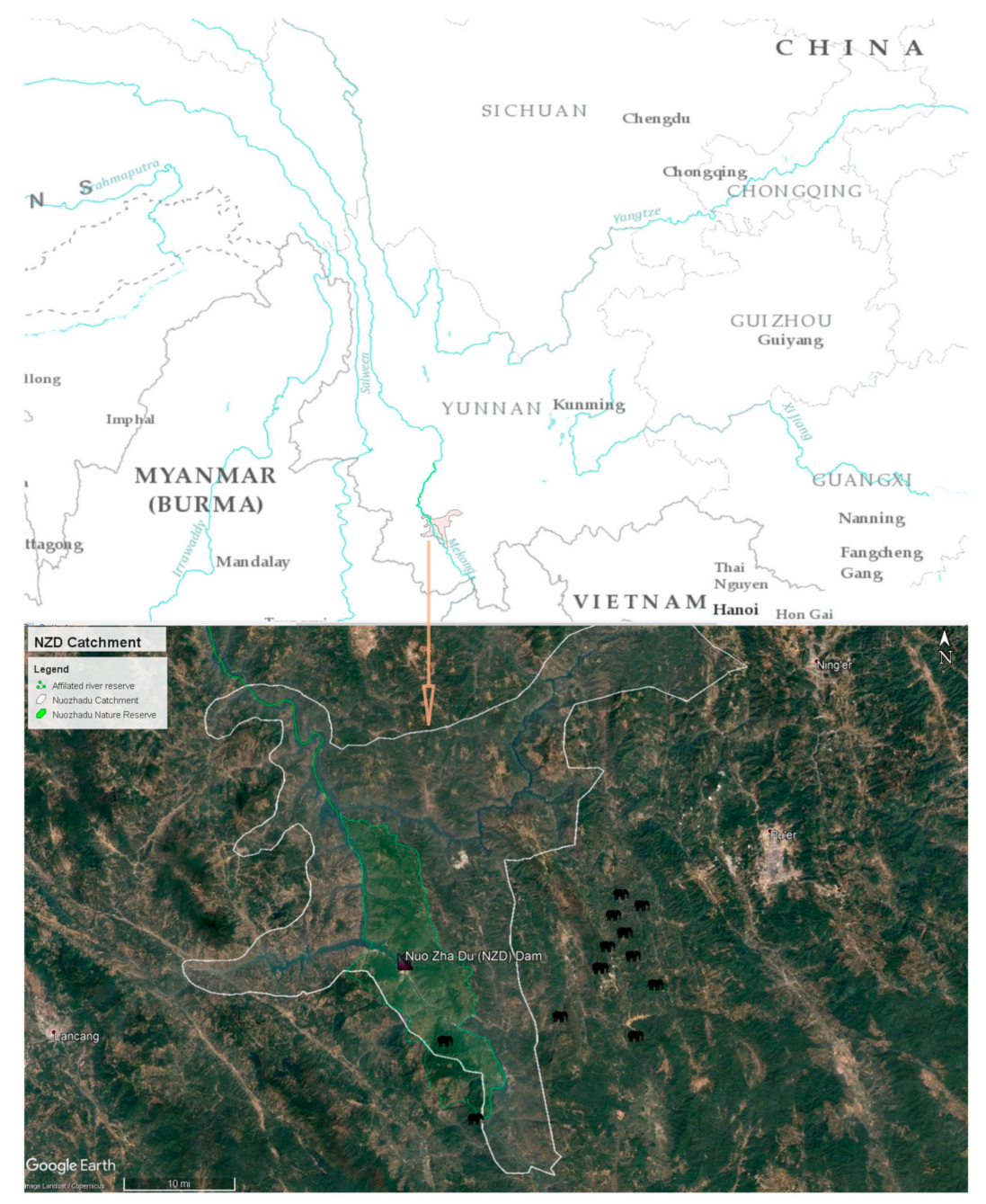

Figure 3. Map of the Nuozhadu (NZD) catchment landscape (inside the white line) and NZD Nature Reserve (inside the green line), and the reported appearing locations of wild elephants (black elephant icons) (Google Earth Image: December 2016). Note: A map of the NZD catchment landscape in December 2003 before constructing the NZD Dam is shown in the Supplementary Figure S3.2.

This case study discusses a landscape designated by the government as the NZD reservoir catchment landscape, the area enclosed by a white line in Figure 3, which comprises lower slopes of the catchment immediately adjoining the reservoir (henceforth called the landscape). The landscape encompasses a displaced population of 46,867 , spanning across two municipalities, nine counties, 32 townships, 113 villages, and 597 village groups [128]. More than 10 indigenous ethnic minorities, including the Lahu People, Yi People, Hani People, Bulan People and Wa People, live in these catchment groups and their lifestyles 
and livelihoods are closed connected with gathering and harvesting wild products in the NZD catchment area [128].

Because of the region's unique topography, geography, and variable regional climate, the NZD Nature Reserve (Figure 3) is an important global hot-spot of biodiversity (identified ecosystem services in the landscape are shown in Table S2 in Supplementary). Various types of vegetation communities grow in the reserve and are spread across the landscape, including tropical rain forests, tropical monsoon forests, evergreen broad-leaf forests, temperate deciduous forests, warm coniferous forests (e.g., Pinud massoniana, Pinus yunnanensisi, and Pinus khasya), bamboo forests, and savanna shrub and grasslands [129]. The flora consists of 171 families, 652 genera, and 1077 species of vascular plants and the fauna includes 96 wild mammal species (e.g., Macaca assamensis, Elephas maximus, Bos gaurus, and Pavo muticus), 257 species of birds, 96 species of reptiles, and 48 species of fish $[129,130]$. The sustainable management of the landscape is a challenge because managers need to use limited capital to reconstruct the livelihoods of the resettlers as well as the broader population living in and around the landscape and conserve the region's abundant flora and fauna. The developer of NZD, the Huaneng Lancang River Hydropower Co. Ltd. (HRHC), claimed that the NZD is a "green and resilient" project that devotes resources to restoration and conservation, promotes local development and takes social responsibility for resettlers [131,132]. However, such assertions on its success in building resilience are questionable based on the following assessment.

\subsection{Data and Methods}

This assessment was carried out based on a mixed methods approach by following the guidelines of Small [133]. The data for this assessment were drawn from a combination of primary and secondary sources. Primary data were collected by the author in December 2017. A second revisit survey was finished in July 2018, and a third revisit was finished in January 2019. Secondary data were retrieved from the datasets of the Chaoxing Discover [134] and the China National Knowledge Infrastructure (CNKI) [135] by searching keywords "Nuozhadu" in Chinese. Details of the mixed-methods methodology applied is shown in Supplementary Table S1.

The Resilience Alliance [86] proposes an issue-based approach to better focus the resilience assessment of SESs on target issues. We propose that a mixed-methods approach serves as an effective theoretical framework to assess the issue-based resilience of complex SESs for three reasons. First, similar to an issue-based approach, a mixed-methods approach is grounded in pragmatism, aiming to solve emerging matters of dispute [136]. Second, the issue-based approach may help resilience assessment focus on the key issues of a complex and uncertain SES and thus avoid being submerged with information [86]. Moreover, a mixed-methods approach can be regarded as an expedient strategy when handling complex issues without clear guidance. Third, assessing a system's resilience is a dynamic process because system dynamics are changing, and our understanding of systems grows as time passes [86]. The issued-based approach is thus a dynamic one capable of addressing the specific conditions of different phases of a system [137]. Notably, the mixed methods approach as we define it above is more flexible and able to change into different forms to integrate qualitative and quantitative research that suits the local context and intended research questions [138]. Finally, it is important to effectively involve stakeholders in the identification of key issues — especially latent but critical system problems-with limited time and resources [139]. Using a mixed-methods approach thus meaningfully takes up crucial issues by absorbing different ranges of evidence and opinions [140].

\subsection{Results}

Our results show that the construction of the NZD significantly changed the resilience of the landscape. Regarding the ecological system, over 1447 hectares of land were flooded (see Figure 3) that were home to many nationally endangered plant species (e.g., Cycas pectinate, Dalbergia fusca, and Toona ciliata) $[141,142]$. Many local insects and animals 
(e.g., Ophiophagus Hannah, Loris tardigradus, Aonyx cinereal, and Bambusicola fytchii) were affected by habitat loss and the cutting-off of their migration routes [130]. However, the reduced resilience of the ecological system was somewhat offset by the Chinese government's considerable efforts to restore the ecology and protect the environment as evident in its establishment of nature reserves and tributary fish reserves, the removal of planted rubber trees, the large-scale resettlement of residents, biodiversity offsets, fish breeding, and fisheries management $[143,144]$. Owing to these efforts for environmental protection and ecological restoration, interviewees $(n=45$, but not all of them responded on every question) reported that the area of forest $(45 / 45)$, water resources $(28 / 45)$, wild resources (23/35, e.g., wild mushrooms, fern, fish), and fauna (38/40) and flora (31/32) species populations have increased in the landscape post-resettlement.

Although natural resources have increased post-resettlement, resettlers are unable to use these resources and this decreased the resilience of the social system. Most participants $(37 / 45)$ said that they could not cultivate their remaining land because of the strict forestry protection regulations (Figure S1 in Supplementary), "super-efficient" monitoring, and high fines [145]. Moreover, resettlers cannot cut the trees (including commercial plantation such as rubber trees) on their land and redevelop the land again for any reason [145] if the trees are over three years old or the diameter of the trees on the ground was more than $10 \mathrm{~cm}$ (Figure S1). Most participatory resettlers (29/42) report that it took them more than three years to move and settle down (i.e., to remove useful materials from old houses and build new houses by themselves) in new locations, and in that time the seedlings on their remaining lands had grown into small trees. One interviewee, $\mathrm{P}(27)$, said:

We moved here but our land is very far from us. Our land (i.e., remaining land) is in very rural alpine areas. As we ultimately built our house here and settled down, we wanted to go back to redevelop our land left in our homeland. However, one staff from forestry public security stopped us and fined me lots of money while I had just cut three of my rubber trees I grew earlier. He told me that my land was left unused for more than three years, and the trees on it cannot be cut according to the forestry legislation.

Moreover, almost all of the resettlers (43/45) responded that their remaining land was expropriated by the local government as public forests. What they received is CNY 10 compensation (i.e., less than USD 2) annually for per $\mathrm{mu}(1 \mathrm{mu}=0.0667$ hectares) of their land. Some participants (15) commented that such compensation is token. $\mathrm{P}(24)$ elaborated on this loss:

Few of my lands are flooded and thus, I just received a little bit of compensation, less than the money I put in building this house. A lot of land, more than $100 \mathrm{mu}$, is still left unused in my old home. The local government just told me that you could go back and continue using your land. Oh goodness, it is hundreds of kilometres away from here. Are you kidding? We do not even have the time and energy to manage the land here. You know that current forest management is so strict; we cannot go back for the trees that have grown so big and so high. We would be fined a lot if we choose to chop them down. Even if there is no fine, we are unable to manage the land here and the old home at the same time.

Another finding is that many communally owned properties like sandpits were expropriated by the local government to mitigate the adverse effects of the NZD Dam and the Jinghong Dam [77] but without any compensation. Eight participants from Village 4 reported that their income has reduced significantly post-resettlement because of losing the income from sand excavation. $\mathrm{P}(30)$ explained:

Formerly, our primary income was from sand excavation. Each member of my family can get at least 200 or 300 yuan per day, at that time... However, as you can see, the sandpit has been occupied by the local government without any negotiation with us.

Indirectly, increased biodiversity has also affected the livelihoods of relocated people. For example, 12 participants mentioned that the increasing biodiversity meant that more 
wild pigs were disturbing the land around the water resources. The emergence of an increasing number of wild mammals like wild pigs and Asian elephants (Figures 3 and 4) not only affected the personal security of people ( 15 out of 45 ) but also had severe effects on water quality and availability (Figure S2 in Supplementary) for many resettlers (28 out of 45). For example, local villagers report that more than four groups of Asian elephants (groups including one, five, eight, and over ten elephants, respectively) frequently emerge at the lower landscape (Figure 3) from January 2019 to August 2019. According to their reports, over 30 people have died from elephant attack from 2017 to 2018, and around 15 killed in the first eight months of 2019 (the latest attack was on 6 August 2019). Elephants also affect the properties of local communities as they eat crops such as corn and bananas and demolish planted crops (e.g., coffee) and damage earthworks while moving (Figure 4).

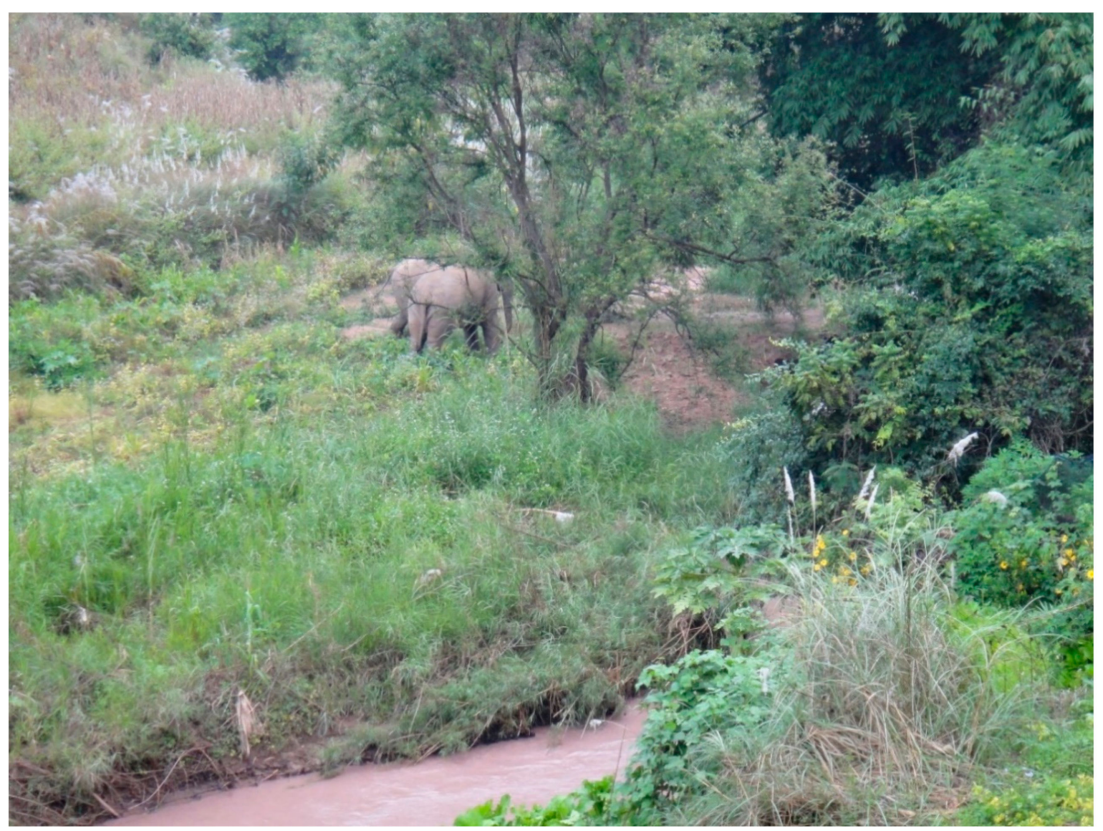

Figure 4. Wild Asian elephants near a participant's land (๔ the author).

A further effect is that many relocated people (34/45) fear the risks that come with being in the forests. For example, 10 participants mentioned that they were afraid of the potential risks from the increasing number of bears and elephants. Before resettlement, two participants earned their primary income, 15 their secondary income, and 25 their extra income from excavation and gathering activities from the mountains, such as gathering herbs and picking wild mushrooms. However, after the increasing numbers of wild boars, snakes, and other dangerous animals, fewer relocated people choose to go to the mountains to gather these products, with the exception of four families who had no other choice because they have not been re-allocated any land post-resettlement to sustain their livelihood.

Local governments chose to prioritise building the ecological system's resilience over livelihoods. For example, we interviewed 10 villagers in Village 1 in December 2017 and found that the primary income of this village came from catching wild fish and aquaculture, as most of their land was either flooded or expropriated by the government as public forest. One interviewee $\mathrm{P}(4)$ stated:

We do not have any land now and we are becoming fishermen. If the government forbids us from catching fish, we will not have any income... What about the next generation? We have the compensation and can catch and breed fish, but they almost have nothing.

However, to protect the water quality, the local government initiated a policy in March 2018 to prohibit "illegal fisheries" in the landscape [144]. The pollution was not primarily caused by these small-scale "illegal" fishermen but rather by the "legal" commercial fishery 
near the villages (according to all participants). We did not find most interviewees from 2017 when we returned in 2018 because most residents who could earn a reliable income chose to migrate for work to nearby towns or cities. What remains are their newly built houses and older adults, people with disabilities, and children, who are unable to work.

\section{Discussion}

The above findings illustrate that it is hard to assess whether the NZD landscape's resilience as a whole has been increased or decreased after relocating the resettlers (Figure 5 and Table 3). Although the available natural resource base significantly increased after resettlement due to local environmental governance, resettlers have been unable to use the resources, either because their use was unlawful or impractical. We built an influence model (Figure 5 and Table 3 ) to elaborate the outcomes and effects of the local governance of the landscape based on the guide of Proust and Newell [146] on constructing influence and casual loop diagrams, which are designed to express people's explanations of why things change over time. From the perspective of distributive environmental justice, the affected communities in the landscape have been disadvantaged [147]. Distributive justice captures the sharing of benefits (resources and services) and burdens (harm and risks) the populace endures [147-150]. Allen et al. [151] find that environmental justice is one of the prerequisites of achieving resilience of SESs. While affected communities in the landscape survived the burdens of displacement and resettlement, they also experienced the increasing risks from increased populations of wild animals, and their access to the natural resource base was decreased because of strict local environmental policies. Most resettlers (37/45) can only choose to work as migrant labourers and gain unstable income after losing access to land, fisheries and other natural resources. The burden falls upon local communities, but the benefits are enjoyed by people regionally, domestically and internationally.

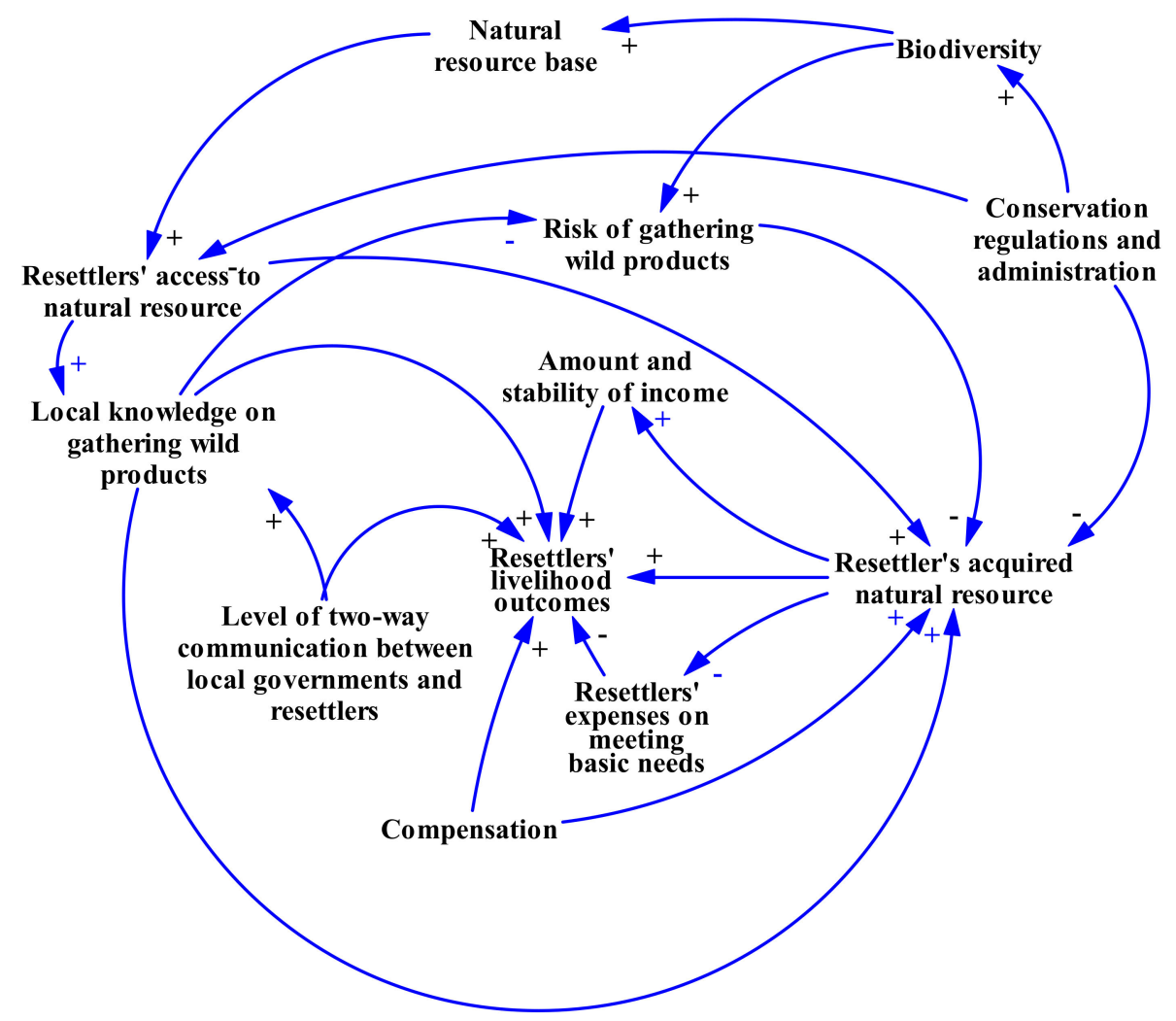

Figure 5. Elaboration of an influence model for the outcomes and effects of local governance of the landscape (Note: "+" means a positive casual relation and "-" means a negative causal relation; definitions and elaborations of the 12 variables are shown in Table 4). 
Table 4. Elaborations, definitions and examples of the 12 variables in the influence model for the outcomes and effects of local governance of the landscape.

\begin{tabular}{|c|c|c|}
\hline \# & Variable & Definition and Examples \\
\hline A & Natural resource base & The total volume of natural resource that is available for local people [152]. \\
\hline B & Biodiversity & $\begin{array}{l}\text { The diversity of species in the landscape. The flora consists of } 171 \text { families, } \\
652 \text { genera, and } 1077 \text { species of vascular plants and the fauna includes } \\
96 \text { wild mammal species (e.g., Macaca assamensis, Elephas maximus, Bos gaurus, } \\
\text { and Pavo muticus), } 257 \text { species of birds, } 96 \text { species of reptiles, and } 48 \text { species } \\
\text { of fish }[129,130] \text {. }\end{array}$ \\
\hline
\end{tabular}

C Resettlers' access to natural resource

D Resettler's acquired natural resource

E Risk of gathering wild products
Conservation regulations and administration
Access by the local people to natural resources, such as land, forests, water, mushrooms, fisheries, nuts, sand pits among others [153].

Acquired natural resource by the local people [153], such as wild products, water, fish and sand.

Risks that local people need to manage while acquiring wild products [154]. Many resettlers (34/45) fear the risks that come with being in the forests. For example, ten participants mentioned that they were afraid of the potential risks from the increasing number of bears and elephants.

Local environmental policies and governance. For example, resettlers cannot cut the trees (including commercial plantation such as rubber trees) on their land and redevelop the land again for any reason [145] if the trees are over three years old or the diameter of the trees on the ground was more than $10 \mathrm{~cm}$.

Resettlers' income and sustainability of their income throughout the year [152]. Most resettlers (37/45) work as part-time or casual migrant labourers gaining unstable income after losing access to land, fisheries and other natural resources. Eight participants from Village 4 reported that their income has reduced significantly post-resettlement because of losing the income from the sand excavation.

The money resettlers' spending on meeting their basic living needs [155]. Most resettlers (37/45) spent more post-resettlement.

$\mathrm{H} \quad$ Resettlers' expenses on meeting basic needs Compensation payments for resettlers' assets losses [156]. 32(/45) resettlers said that the received compensation was not enough to build a new house in new resettlement sites.

Local knowledge, social and cultural connections with the landscape accumulated by local communities through their history on gathering wild products [157]. For example, traditional local knowledge populations the living of some local species, especially fungus such as Ramaria botrytoides, Lasiosphaera seu Calvatia and Russula virescens.

gathering wild products

$\mathrm{K}$

Level of two-way communication between local governments and resettlers

The effectiveness of communications or quality of dialogues between local government and resettlers, normally under respectful, fair and open communicative environment $[158,159]$. Local governments chose to prioritise building the ecological system's resilience over livelihoods automatically without sufficient communications with resettlers because they believed that communities' livelihoods and well-being should improve as long as the ecological conditions have improved.

Resettlers' livelihood outcomes are the achievements or outputs on increasing resettlers' income, well-being, food security and sustainable use of the natural resources base and reducing vulnerability [152]. The NZD case study demonstrates that livelihood reconstruction and improvement is one of the biggest challenges for resilient landscape management, involving trade-offs between sustaining people and the environment, and between sustainable development for people at different scales.

The Chinese case study is not unusual. Organisations like the World Bank have been recasting projects such as hydroelectric dams as building global resilience to climate change but at the cost of damaging local people's culture and livelihoods [106,160]. In addition, 
Béné et al. (2014) found that building resilience cannot replace reducing poverty and increasing well-being. Thus, we argue that "resilience for whom" should be parallel to "resilience of what to what" if the concept of resilience in landscape management is to be just. Although "resilience for whom" has been included in some recent frameworks (like the one developed by Dewulf et al. [95]), prevailing frameworks of applying resilience such as the one by Sellberg et al. [161] and the Resilience Assessment Framework [86] do not include it. Including "resilience for whom" will not only help to identify justice issues but also aid our understanding of multi-scale dynamics; for example, building global resilience to climate change vs. diminishing local resilience by detracting from sustainable income and food security.

The when, where, and why of the difficulties of resilience have only been addressed by a few studies, such as by Meerow and Newell [16]. The how and can of difficulties have not been clearly addressed by a case study that we could locate. The how difficulty may need to be more directly and clearly addressed beyond simply emphasising self-governance, or social learning in a complex and contingent world. Otherwise, this self-governance solution to complexity and uncertainty may just generate more complexity and uncertainty, as pointed out by Duit et al. [92]. "If we understand self-governance as something like the ability of the governor to guide society along a preferred path - be it toward ideal justice, the maximisation of welfare, national community, or socialism-we have constructed a social world that is too complex for self-governance of any sort, democratic or not" (p. 968) [115]. Significantly, the last category, "can", has been largely ignored by ecologists and managers $[43,73,87,89]$. The "can" question needs to be considered as it will help landscape managers to examine their assumptions underpinning their planning and management strategies. For example, the management of the landscape is also subject to a national strategy called "ecological civilisation" to conserve ecology, build resilience, and support China's sustainability transition [162,163]. This builds on the "double-mountain" (两山理 论) national conservation directive: "clear waters and green mountains are as valuable as gold and silver mountains" (绿水青山就是金山银山) formulated by Chinese Chairman Xi Jinping [164]. In other words, communities' livelihoods and well-being should improve as long as the ecological conditions have improved because people's livelihood is assumed to be primarily concerned with the ecological system (Figure 6) [101]. This assumption could be right when applied to some communities, especially the poor whose livelihoods are restricted by diminishing ecology [165].

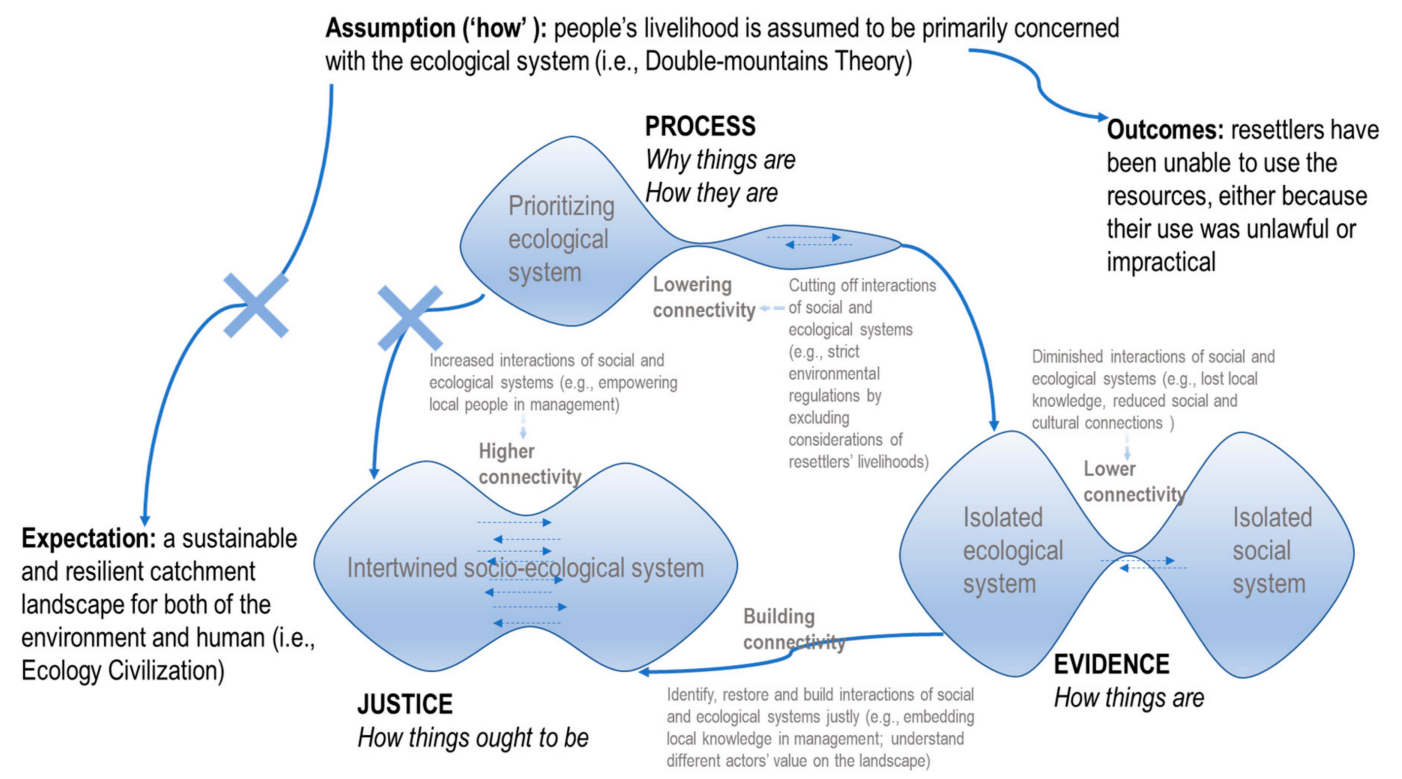

Figure 6. Focal-scale system change and environmental justice claim-making in the NZD landscape (Source: author, adapted from the environmental justice claim-making framework developed by (p. 40) [147]. 
However, we found that the livelihoods of resettlers in the landscape have not improved with environmental restoration. Most resettlers (37/45) spent more post-resettlement on meeting their basic living needs after losing access to land, fisheries and other natural resources. The socio-ecological relationships in the landscape are more complex than the managers anticipated, such as with the emergence of wild mammals and their impact on water quality. As a result, this management strategy may not build resilience as the interactions of social and ecological systems are diminished (Figure 6). The profound local knowledge and social and cultural connections with the landscape accumulated by local communities over thousands of years are being lost $[129,130]$. For example, local knowledge such as the distribution and characteristics of some plants and fungi in the landscape (Figure 7) would be lost if local residents stopped gathering them in the mountains of the landscape. Moreover, traditional local knowledge is tied to the living and reproduction of some local species, especially fungi such as Ramaria botrytoides, Lasiosphaera seu Calvatia, and Russula virescens. Some of these species (Figure 7), such as Litsea and Pyrus pashia Buch.-Ham. ex D. Don, have co-evolved with the local communities of ethnic minorities [166,167] and thus some local activities (e.g., grazing livestock periodically) are necessary to sustain biodiversity [168]. Thus, current environmental governance to safeguard natural resources will isolate the local communities and ecological system in two "separate" systems with lower connectivity as the result of diminished interactions between social and ecological systems of the landscape (Figure 6). Connectivity in SESs facilitates the exchange of material and information functioning processes of the social and ecological systems [169]. After cutting off the daily and seasonal interactions between the local communities and the landscape, the resilience of the landscape may ultimately decline rather than increase as expected (Figure 6). In addition, a greater diversity of available actions in SESs is believed by scholars to be higher resilience when a system has to deal with shocks and stresses [104]. Limiting available actions of residents in the landscape as shown above also reduce its resilience.

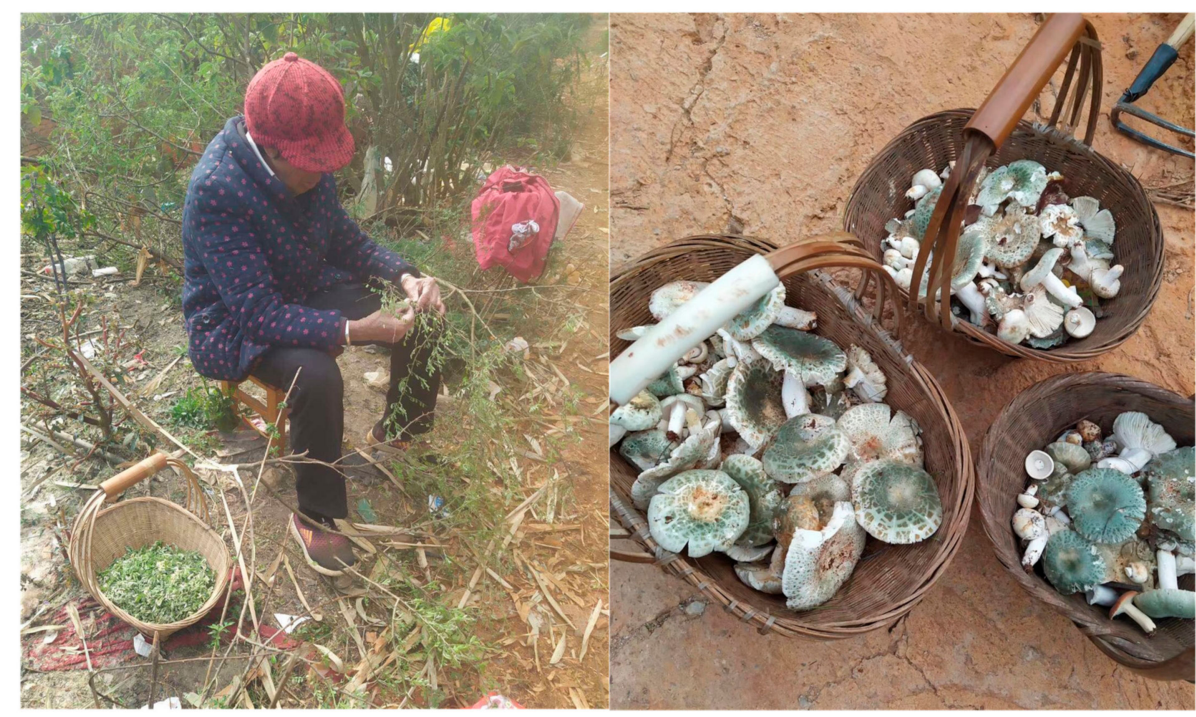

Figure 7. Local knowledge of gathering wild products: Pyrus pashia Buch.-Ham. ex D. Don (left) and Russula virescens (right) (Photo: (C) the author).

A resilient system is supposed to learn from a disturbance and avoid or better cope with a similar disturbance in the future [55]. An assumption is that a system "can" draw on past experience and learn through individuals, but this assumption has been questioned by some social scientists as they find that institutions and organisation in the system may not have the same learning ability as individuals [74,87]. Here, we are not aiming to participate in this debate but instead emphasise the power issues underpinning normative resilience. In short, higher resilience, such as higher pathway diversity, is not necessarily desirable [104]. Thus, even if the institutions and organisations in a system "can" draw on 
past disturbance and perform better in further disasters, the individuals in the institutions and organisations are generally struggling to maximise their power and affluence [87]. Thus, resilience was not improved as planned because measures were not adopted at the beginning to reconcile competing interests and develop solid implementation protocols [16]. For example, the loss of arable land is one of the main factors preventing resettlers from getting a sustainable income and achieving food security [80,170-173]. Allocating enough lands to resettled communities has been a goal (i.e., Goal 5) of the Chinese resettlement policy [174]. However, local governments are afraid of both the financial and environmental costs of cultivating new land [174-176] for resettlers and instead intentionally minimise the areas of re-allocated land $(21 / 45)$ or prioritise non-land resettlement options, without involving stakeholders (especially resettlers and lower authorities) in these decisions [177].

As a case study with a mixture of primary and secondary sources of data, our findings cannot quantify the change in the resilience of the landscape and show all humanenvironment interactions. Our analysis is also constrained as research was limited to three visits to the landscape, as assessing resilience is time-sensitive [86]. More research and more regular visits are needed that positively engage local communities in discussing how to improve their livelihoods while protecting the landscape's ecology to achieve resilient SESs. Nonetheless, the available evidence and our analysis highlight the need to consider the seven difficulties in resilience planning for just and sustainable landscape development.

\section{Conclusions}

Resilience represents an ability to live, learn from, and develop with changes, some of which are unpredictable $[46,53,56,85]$. It is unavoidable that our understandings of these complexities will be incomplete as these systems are dynamic and may have unpredictable characteristics. From this perspective, building landscape resilience could be an effective management strategy for coordinating the needs of different actors who are dependent on the landscape only as long as the approaches proposed or initiated by managers or researchers can enhance the landscape's ability to coexist with changes and uncertainties justly $[46,178]$.

However, building resilience without clear targets and boundaries has perverse impacts. Some groups consume resources and services at the expense of others. Seven categories of difficulties have been defined that should be addressed when using resilience concepts to instruct management, namely resilience for whom, what, when, when, where, why, as well as can and how we apply resilience. Using the seven difficulties to question management strategies and plans can identify assumptions behind building resilience to achieve more just and sustainable outcomes more transparently. We find these difficulties are generally overlooked and avoided despite their instructive roles to achieve just landscape management. The NZD case demonstrates that building the NZD's resilience has reduced to conserve the NZD's ecology and overlooks trade-offs between sustaining people and the environment, and between sustainable development for people at different scales. Similar conflicts between conservation and development have also been reported by scholars like Zhang [67] and Ding [177] in assessing the pastoral landscape. Researchers, managers, and other decision-makers need to think about resilience more normatively and address the questions we summarise in the framework before approaching building landscape resilience. In addition, undesirable resilience, as highlighted by Dornelles et al. [21], deserves more attention to avoid blurring claims, such as building the resilience of the whole system or country without identifying the trade-offs and causing undesirable harm to local people and ecosystems.

Supplementary Materials: The following are available online at https:/ /www.mdpi.com/2071-1 050/13/5/2629/s1, Figure S1: Conditions of some resettlers' unflooded or allocated land postresettlement, Figure S2: Unsanitary potable water supplied to a resettler's home, Figure S3.1: Map of the NZD catchment after dam completion in December 2016 (inside the white line) and NZD Nature Reserve (inside the green line), and the reported appearing locations of wild elephants (black elephant icons), Figure S3.2: December 2003-map of the NZD catchment before dam completion 
in December 2003 (inside the white line) and NZD Nature Reserve (inside the green line), and reported appearing locations of wild elephants (black elephant icons), Table S1. Application of the methodology of resilience assessment in the NZD reservoir landscape, Table S2. Identified ecosystem services of the NZD landscape, Interviewing outline.

Author Contributions: Conceptualization, H.X.; methodology, H.X. and M.P.; software, H.X.; validation, H.X., M.P. and J.P.; formal analysis, H.X. M.P. and J.P. investigation, H.X.; resources, H.X. and M.P. and J.X.; data curation, H.X. and M.P.; writing-original draft preparation, H.X. and M.P.; writing-review and editing, H.X. and J.P.; visualization, H.X. and J.P.; supervision, J.P. and J.X.; project administration, H.X. and M.P.; funding acquisition, H.X., M.P. and J.X. All authors have read and agreed to the published version of the manuscript.

Funding: This work was supported by the Key Foundation of China Academy of Engineering Physics, China (Grant No. 2019-ZD-012); the China Postdoctoral Innovative Talents Program (Grant No. BX201907170); and the China Scholarship Council (CSC) (Grant No. 201808190012).

Institutional Review Board Statement: The study was conducted according to the guidelines of the Declaration of Helsinki, and approved by the Institutional Review Board (or Ethics Committee) of ANU Human Research Ethics (protocol code: \#2017/594, approved on 25 October 2017)."

Informed Consent Statement: Informed consent was obtained from all subjects involved in the study.

Data Availability Statement: Some or all data, models, or code that support the findings of this study are available from the corresponding author upon reasonable request.

Acknowledgments: We are grateful to Brian Walker, whose critical and constructive feedback helped to improve the article. We thank the four anonymous reviewers who helped refine this work.

Conflicts of Interest: All authors declare that they have no conflict of interest or financial conflicts to disclose. All interviews were undertaken under ANU Human Research Ethics Approval \#2017/594.

\section{References}

1. Harbi, J.; Erbaugh, J.T.; Sidiq, M.; Haasler, B.; Nurrochmat, D.R. Making a bridge between livelihoods and forest conservation: Lessons from non timber forest products' utilisation in South Sumatera, Indonesia. For. Policy Econ. 2018, 94, 1-10. [CrossRef]

2. Hasler, B.; Hyytiäinen, K.; Refsgaard, J.C.; Smart, J.C.R.; Tonderski, K. Sustainable ecosystem governance under changing climate and land use: An introduction. Ambio 2019, 48, 1235-1239. [CrossRef] [PubMed]

3. Vos, W.; Meekes, H. Trends in European cultural landscape development: Perspectives for a sustainable future. Landsc. Urban Plan. 1999, 46, 3-14. [CrossRef]

4. Termorshuizen, J.W.; Opdam, P. Landscape services as a bridge between landscape ecology and sustainable development. Landsc. Ecol. 2009, 24, 1037-1052. [CrossRef]

5. Zari, M.P. Regenerative Urban Design and Ecosystem Biomimicry; Routledge: New York, NY, USA, 2018.

6. Tudor, C. An Approach to Landscape Character Assessment; Natural England: York, UK, 2014.

7. Solecka, I.; Raszka, B.; Krajewski, P. Landscape analysis for sustainable land use policy: A case study in the municipality of Popielów, Poland. Land Use Policy 2018, 75, 116-126. [CrossRef]

8. Bailey, I.; Buck, L.E. Managing for resilience: A landscape framework for food and livelihood security and ecosystem services. Food Secur. 2016, 8, 477-490. [CrossRef]

9. Vallés-Planells, M.; Galiana, F.; Torrijos, I.D. Agricultural abandonment and resilience in a Mediterranean periurban traditional agroecosystem: A landscape approach. Ecol. Soc. 2020, 25. [CrossRef]

10. Ahern, J. Urban landscape sustainability and resilience: The promise and challenges of integrating ecology with urban planning and design. Landsc. Ecol. 2013, 28, 1203-1212. [CrossRef]

11. Lei, K.; Pan, H.; Lin, C. A landscape approach towards ecological restoration and sustainable development of mining areas. Ecol. Eng. 2016, 90, 320-325. [CrossRef]

12. Cantarello, E.; Newton, A.C.; Martin, P.A.; Evans, P.M.; Gosal, A.; Lucash, M.S. Quantifying resilience of multiple ecosystem services and biodiversity in a temperate forest landscape. Ecol. Evol. 2017, 7, 9661-9675. [CrossRef] [PubMed]

13. Dearing, J. Landscape change and resilience theory: A palaeoenvironmental assessment from Yunnan, SW China. Holocene 2008, 18, 117-127. [CrossRef]

14. Chang, Y.; Wilkinson, S.; Potangaroa, R.; Seville, E. Resourcing challenges for post-disaster housing reconstruction: A comparative analysis. Build. Res. Inf. 2010, 38, 247-264. [CrossRef]

15. Allan, P.; Bryant, M. Resilience as a framework for urbanism and recovery. J. Landsc. Arch. 2011, 6, 34-45. [CrossRef]

16. Meerow, S.; Newell, J.P. Urban resilience for whom, what, when, where, and why? Urban Geogr. 2019, 40, 309-329. [CrossRef]

17. Plieninger, T.; Bieling, C. Resilience and the Cultural Landscape: Understanding and Managing Change in Human-Shaped Environments; Cambridge University Press: Cambridge, UK, 2012. 
18. Duveneck, M.J.; Scheller, R.M. Measuring and managing resistance and resilience under climate change in northern Great Lake forests (USA). Landsc. Ecol. 2015, 31, 669-686. [CrossRef]

19. Wiens, J.A. Is landscape sustainability a useful concept in a changing world? Landsc. Ecol. 2012, 28, 1047-1052. [CrossRef]

20. Colloff, M.; Gorddard, R.; Dunlop, M. The Values-Rules-Knowledge Framework in Adaptation Decision-Making: A Primer; CSIRO Land and Water: Canberra, Australia, 2018.

21. Dornelles, A.Z.; Boyd, E.; Nunes, R.J.; Asquith, M.; Boonstra, W.J.; Delabre, I.; Denney, J.M.; Grimm, V.; Jentsch, A.; Nicholas, K.A.; et al. Towards a bridging concept for undesirable resilience in social-ecological systems. Glob. Sustain. 2020, 3, 20. [CrossRef]

22. Mačić, V.; Albano, P.G.; Almpanidou, V.; Claudet, J.; Corrales, X.; Essl, F.; Evagelopoulos, A.; Giovos, I.; Jimenez, C.; Kark, S.; et al. Biological Invasions in Conservation Planning: A Global Systematic Review. Front. Mar. Sci. 2018, 5, 13. [CrossRef]

23. Munn, Z.; Peters, M.D.J.; Stern, C.; Tufanaru, C.; McArthur, A.; Aromataris, E. Systematic review or scoping review? Guidance for authors when choosing between a systematic or scoping review approach. BMC Med Res. Methodol. 2018, 18, 1-7. [CrossRef] [PubMed]

24. Lott, C.A.; Akresh, M.E.; Elmore, A.J.; Fiss, C.J.; Fitzpatrick, M.C.; Joos, C.J.; King, D.I.; McNeil, D.J.; Stoleson, S.H.; Larkin, J.L. What evidence exists for landbird species-environment relationships in eastern temperate and boreal forests of North America? A systematic map protocol. Environ. Évid. 2019, 8, 9. [CrossRef]

25. Arksey, H.; O'Malley, L. Scoping studies: Towards a methodological framework. Int. J. Soc. Res. Methodol. 2005, 8, 19-32. [CrossRef]

26. Van ECK, N.; Waltman, L. Software survey: VOSviewer, a computer program for bibliometric mapping. Scientometrics 2010, 84, 523-538. [CrossRef]

27. Van Eck, N.J.; Waltman, L. Citation-based clustering of publications using CitNetExplorer and VOSviewer. Scientometrics 2017, 111, 1053-1070. [CrossRef]

28. Axelsson, R.; Angelstam, P.; Elbakidze, M.; Stryamets, N.; Johansson, K.-E. Sustainable Development and Sustainability: Landscape Approach as a Practical Interpretation of Principles and Implementation Concepts. J. Landsc. Ecol. 2011, 4, 5-30. [CrossRef]

29. Lassus, B. The Landscape Approach; University of Pennsylvania Press: Philadelphia, PA, USA, 1998.

30. DeFries, R.; Rosenzweig, C. Toward a whole-landscape approach for sustainable land use in the tropics. Proc. Natl. Acad. Sci. USA 2010, 107, 19627-19632. [CrossRef] [PubMed]

31. Arts, B.; Buizer, M.; Horlings, L.; Ingram, V.; Van Oosten, C.; Opdam, P. Landscape Approaches: A State-of-the-Art Review. Annu. Rev. Environ. Resour. 2017, 42, 439-463. [CrossRef]

32. Kessler, W.B.; Salwasser, H.; Cartwright, C.W., Jr.; Caplan, J.A. New Perspectives for Sustainable Natural Resources Management. Ecol. Appl. 1992, 2, 221-225. [CrossRef] [PubMed]

33. Baron, J.S.; Poff, N.L.; Angermeier, P.L.; Dahm, C.N.; Gleick, P.H.; Hairston, N.G.; Jackson, R.B.; Johnston, C.A.; Richter, B.D.; Steinman, A.D. Meeting Ecological and Societal Needs for Freshwater. Ecol. Appl. 2002, 12, 1247-1260. [CrossRef]

34. Carter, M.R. Soil quality for sustainable land management: Organic matter and aggregation interactions that maintain soil functions. Agron. J. 2002, 94, 38-47. [CrossRef]

35. Zuazo, V.H.D.; Pleguezuelo, C.R.R. Soil-erosion and runoff prevention by plant covers. A review. Agron. Sustain. Dev. 2008, 28, 65-86. [CrossRef]

36. Kromp, B. Carabid beetles in sustainable agriculture: A review on pest control efficacy, cultivation impacts and enhancement. Agric. Ecosyst. Environ. 1999, 74, 187-228. [CrossRef]

37. Bianchi, F.; Booij, C.; Tscharntke, T. Sustainable pest regulation in agricultural landscapes: A review on landscape composition, biodiversity and natural pest control. Proc. R. Soc. B Boil. Sci. 2006, 273, 1715-1727. [CrossRef]

38. Lindenmayer, D.B.; Margules, C.R.; Botkin, D.B. Indicators of Biodiversity for Ecologically Sustainable Forest Management. Conserv. Biol. 2000, 14, 941-950. [CrossRef]

39. Jeffries, P.; Gianinazzi, S.; Perotto, S.; Turnau, K.; Barea, J.-M. The contribution of arbuscular mycorrhizal fungi in sustainable maintenance of plant health and soil fertility. Biol. Fertil. Soils 2003, 37, 1-16. [CrossRef]

40. Gray, R.; Milne, M. Sustainability reporting: Who's kidding whom? Chart. Account. J. N. Z. 2002, 81, 66-70.

41. Millennium Ecosystem Assessment. Ecosystems and Human Well-Being: Wetlands and Water Synthesis; Island Press: Washington, DC, USA, 2005.

42. Scheffer, M.; Carpenter, S.; Foley, J.A.; Folke, C.; Walker, B.R. Catastrophic shifts in ecosystems. Nat. Cell Biol. 2001, 413, 591-596. [CrossRef] [PubMed]

43. Lawhon, M.; Murphy, J.T. Socio-technical regimes and sustainability transitions: Insights from political ecology. Prog. Hum. Geogr. 2011, 36, 354-378. [CrossRef]

44. Marsden, T. From post-productionism to reflexive governance: Contested transitions in securing more sustainable food futures. J. Rural. Stud. 2013, 29, 123-134. [CrossRef]

45. Kløve, B.; Ala-Aho, P.; Bertrand, G.; Gurdak, J.J.; Kupfersberger, H.; Kværner, J.; Muotka, T.; Mykrä, H.; Preda, E.; Rossi, P.; et al. Climate change impacts on groundwater and dependent ecosystems. J. Hydrol. 2014, 518, 250-266. [CrossRef]

46. Moritz, M.A.; Batllori, E.; Bradstock, R.A.; Gill, A.M.; Handmer, J.; Hessburg, P.F.; Leonard, J.; McCaffrey, S.; Odion, D.C.; Schoennagel, T.; et al. Learning to coexist with wildfire. Nat. Cell Biol. 2014, 515, 58-66. [CrossRef]

47. Barrow, C.J. Environmental Management for Sustainable Development; Routledge: New York, NY, USA, 2006.

48. Bürgi, M.; Ali, P.; Chowdhury, A.; Heinimann, A.; Hett, C.; Kienast, F.; Mondal, M.K.; Upreti, B.R.; Verburg, P.H. Integrated Landscape Approach: Closing the Gap between Theory and Application. Sustainability 2017, 9, 1371. [CrossRef] 
49. Ostrom, E. Governing the Commons: The Evolution of Institutions for Collective Action; Cambridge University Press: Cambridge, UK, 1990.

50. Ostrom, E. A diagnostic approach for going beyond panaceas. Proc. Natl. Acad. Sci. USA 2007, 104, 15181-15187. [CrossRef]

51. Ostrom, E. A general framework for analysing sustainability of social-ecological systems. Science 2009, 325, 419-422. [CrossRef]

52. Ratzlaff, E.D. Applications of Engineering Systems Analysis to the Human Social-Ecological System; University of California, Davis: Davis, CA, USA, 1969.

53. Berkes, F.; Folke, C.; Colding, J. Linking Social and Ecological Systems: Management Practices and Social Mechanisms for Building Resilience; Cambridge University Press: Cambridge, UK, 1998.

54. Colding, J.; Barthel, S. Exploring the social-ecological systems discourse 20 years later. Ecol. Soc. 2019, 24. [CrossRef]

55. Walker, B. Resilience: What it is and is not. Ecol. Soc. 2020, 25, 11. [CrossRef]

56. Biggs, R.; Schlüter, M.; Schoon, M.L. Principles for Building Resilience: Sustaining Ecosystem Services in Social-Ecological Systems; Cambridge University Press: Cambridge, UK, 2015.

57. Folke, C. Resilience (Republished). Ecol. Soc. 2016, 21. [CrossRef]

58. Liu, J.; Dietz, T.; Carpenter, S.R.; Folke, C.; Alberti, M.; Redman, C.L.; Schneider, S.H.; Ostrom, E.; Pell, A.N.; Lubchenco, J.; et al. Coupled Human and Natural Systems. Ambio 2007, 36, 639-649. [CrossRef]

59. Carpenter, S.R.; Mooney, H.A.; Agard, J.; Capistrano, D.; DeFries, R.S.; Díaz, S.; Dietz, T.; Duraiappah, A.K.; Oteng-Yeboah, A.; Pereira, H.M.; et al. Science for managing ecosystem services: Beyond the Millennium Ecosystem Assessment. Proc. Natl. Acad. Sci. USA 2009, 106, 1305-1312. [CrossRef] [PubMed]

60. Cumming, G.S.; Allen, C.R.; Ban, N.C.; Biggs, D.; Biggs, H.C.; Cumming, D.H.M.; De Vos, A.; Epstein, G.; Etienne, M.; Maciejewski, K.; et al. Understanding protected area resilience: A multi-scale, social-ecological approach. Ecol. Appl. 2015, 25, 299-319. [CrossRef] [PubMed]

61. Schlüter, M.; Haider, L.J.; Lade, S.J.; Lindkvist, E.; Martin, R.; Orach, K.; Wijermans, N.; Folke, C. Capturing emergent phenomena in social-ecological systems: An analytical framework. Ecol. Soc. 2019, 24. [CrossRef]

62. Sikula, N.R.; Mancillas, J.W.; Linkov, I.; McDonagh, J.A. Risk management is not enough: A conceptual model for resilience and adaptation-based vulnerability assessments. Environ. Syst. Decis. 2015, 35, 219-228. [CrossRef]

63. Nunes, D.M.; Tomé, A.; Pinheiro, M.D. Urban-centric resilience in search of theoretical stabilisation? A phased thematic and conceptual review. J. Environ. Manag. 2019, 230, 282-292. [CrossRef]

64. Carpenter, S.R.; DeFries, R.; Dietz, T.; Mooney, H.A.; Polasky, S.; Reid, W.V.; Scholes, R.J. ECOLOGY: Enhanced: Millennium Ecosystem Assessment: Research Needs. Science 2006, 314, 257-258. [CrossRef]

65. Daily, G.C.; Matson, P.A. Ecosystem services: From theory to implementation. Proc. Natl. Acad. Sci. USA 2008, 105, 9455-9456. [CrossRef]

66. Vihervaara, P.; Rönkä, M.; Walls, M. Trends in Ecosystem Service Research: Early Steps and Current Drivers. Ambio 2010, 39, 314-324. [CrossRef] [PubMed]

67. Zhang, Q. Managing sandstorms through resettling pastoralists in China: How multiple forms of power govern the environment at/across scales. J. Political Ecol. 2018, 25, 364-380. [CrossRef]

68. Noordwijk, M.V. Integrated natural resource management as pathway to poverty reduction: Innovating practices, institutions and policies. Agric. Syst. 2019, 172, 60-71. [CrossRef]

69. Holling, C.S. Resilience and Stability of Ecological Systems. Annu. Rev. Ecol. Syst. 1973, 4, 1-23. [CrossRef]

70. Folke, C. Resilience: The emergence of a perspective for social-ecological systems analyses. Glob. Environ. Chang. 2006, 16, 253-267. [CrossRef]

71. Brown, H. Infrastructural Ecology: Embedding Resilience in Public Works. Public Work. Manag. Policy 2019, 24, 20-32. [CrossRef]

72. Klein, R.J.; Nicholls, R.J.; Thomalla, F. Resilience to natural hazards: How useful is this concept? Glob. Environ. Chang. Part B Environ. Hazards 2004, 5, 35-45. [CrossRef]

73. Béné, C.; Wood, R.G.; Newsham, A.; Davies, M. Resilience: New Utopia or New Tyranny? Reflection about the Potentials and Limits of the Concept of Resilience in Relation to Vulnerability Reduction Programmes. IDS Work. Pap. 2012, 2012, 1-61. [CrossRef]

74. Davoudi, S.; Shaw, K.; Haider, L.J.; Quinlan, A.E.; Peterson, G.D.; Wilkinson, C.; Fünfgeld, H.; McEvoy, D.; Porter, L. Resilience: A Bridging Concept or a Dead End? "Reframing" Resilience: Challenges for Planning Theory and Practice Interacting Traps: Resilience Assessment of a Pasture Management System in Northern Afghanistan Urban Resilience: What Does it Mean in Planning Practice? Resilience as a Useful Concept for Climate Change Adaptation? The Politics of Resilience for Planning: A Cautionary Note. Plan. Theory Pr. 2012, 13, 299-333. [CrossRef]

75. Ziv, G.; Baran, E.; Nam, S.; Rodríguez-Iturbe, I.; Levin, S.A. Trading-off fish biodiversity, food security, and hydropower in the Mekong River Basin. Proc. Natl. Acad. Sci. USA 2012, 109, 5609-5614. [CrossRef] [PubMed]

76. Deng, X.; Li, Z.; Gibson, J. A review on trade-off analysis of ecosystem services for sustainable land-use management. J. Geogr. Sci. 2016, 26, 953-968. [CrossRef]

77. Xu, H.; Pittock, J. Limiting the effects of hydropower dams on freshwater biodiversity: Options on the Lancang River, China. Mar. Freshw. Res. 2019, 70, 169. [CrossRef]

78. Xu, H.; Pittock, J. Policy changes in dam construction and biodiversity conservation in the Yangtze River Basin, China. Mar. Freshw. Res. 2021, 72, 228. [CrossRef] 
79. Pittock, J. Trade-Offs Between Hydropower Development and Food Security in River Management. In Population, Development, and the Environment; Springer International Publishing: Singapore, 2019; pp. 53-68.

80. Wilmsen, B. After the Deluge: A longitudinal study of resettlement at the Three Gorges Dam, China. World Dev. 2016, 84, 41-54. [CrossRef]

81. Yan, D.; Shi, G.; Hu, Z.; Wang, H. Resettlement for the Danjiangkou Dam heightening project in China: Planning, implementation and effects. Int. J. Water Resour. Dev. 2016, 33, 609-627. [CrossRef]

82. Resilience Alliance. Research of Resilience Alliance; Resilience Alliance: Stockholm, Sweden, 2019; Available online: https: / / www.resalliance.org/research (accessed on 5 May 2019).

83. Santa Fe Institute. Research of Santa Fe Institute; Santa Fe Institute: Santa Fe, NM, USA, 2019; Available online: https:/ /www santafe.edu/ (accessed on 5 May 2019).

84. Goulburn Broken Catchment Mangement Authority. Goulburn Broken Regional Catchment Strategy (2013-2019); Goulburn Broken Catchment Management Authority: Shepparton, Australia, 2013.

85. Quinlan, A.E.; Berbés-Blázquez, M.; Haider, L.J.; Peterson, G.D. Measuring and assessing resilience: Broadening understanding through multiple disciplinary perspectives. J. Appl. Ecol. 2016, 53, 677-687. [CrossRef]

86. Resilience Alliance. Assessing Resilience in Social-Ecological Systems: Workbook for Practitoners 2.0; Resilience Alliance: Stockholm, Sweden, 2010.

87. Hornborg, A. Zero-sum world: Challenges in conceptualising environmental load displacement and ecologically unequal exchange in the world-system. Int. J. Comp. Sociol. 2009, 50, 237-262. [CrossRef]

88. Davidson, D.J. The Applicability of the Concept of Resilience to Social Systems: Some Sources of Optimism and Nagging Doubts. Soc. Nat. Resour. 2010, 23, 1135-1149. [CrossRef]

89. Cote, M.; Nightingale, A.J. Resilience thinking meets social theory: Situating social change in socio-ecological systems (SES) research. Prog. Hum. Geogr. 2011, 36, 475-489. [CrossRef]

90. Cretney, R. Resilience for Whom? Emerging Critical Geographies of Socio-ecological Resilience. Geogr. Compass 2014, 8, 627-640. [CrossRef]

91. Welsh, M. Resilience and responsibility: Governing uncertainty in a complex world. Geogr. J. 2014, 180, 15-26. [CrossRef]

92. Duit, A.; Galaz, V.; Eckerberg, K.; Ebbesson, J. Governance, complexity, and resilience. Glob. Environ. Chang. 2010, 20, 363-368. [CrossRef]

93. Brown, K. Global environmental change I: A social turn for resilience? Prog. Hum. Geogr. 2014, 38, 107-117. [CrossRef]

94. Olsson, P.; Galaz, V.; Boonstra, W.J. Sustainability transformations: A resilience perspective. Ecol. Soc. 2014, 19. [CrossRef]

95. Dewulf, A.; Karpouzoglou, T.; Warner, J.; Wesselink, A.; Mao, F.; Vos, J.; Tamas, P.; Groot, A.E.; Heijmans, A.; Ahmed, F.; et al. The power to define resilience in social-hydrological systems: Toward a power-sensitive resilience framework. Wiley Interdiscip. Rev. Water 2019, 6, 1377. [CrossRef]

96. Mackinnon, D.; Derickson, K.D. From resilience to resourcefulness: A critique of resilience policy and activism. Prog. Hum. Geogr. 2012, 37, 253-270. [CrossRef]

97. Cretney, R.; Bond, S. 'Bouncing back' to capitalism? Grass-roots autonomous activism in shaping discourses of resilience and transformation following disaster. Resilience 2014, 2, 18-31. [CrossRef]

98. Ebbesson, J. The rule of law in governance of complex socio-ecological changes. Glob. Environ. Chang. 2010, 20, 414-422. [CrossRef]

99. Joseph, J. Resilience as embedded neoliberalism: A governmentality approach. Resilience 2013, 1, 38-52. [CrossRef]

100. Adger, W.N. Social and ecological resilience: Are they related? Prog. Hum. Geogr. 2000, 24, 347-364. [CrossRef]

101. Fabinyi, M.; Evans, L.; Foale, S.J. Social-ecological systems, social diversity, and power: Insights from anthropology and political ecology. Ecol. Soc. 2014, 19. [CrossRef]

102. Béné, C.; Newsham, A.; Davies, M.; Ulrichs, M.; Godfrey-Wood, R. Review article: Resilience, poverty and development. J. Int. Dev. 2014, 26, 598-623. [CrossRef]

103. Walker, B.; Salt, D. Resilience Practice: Building Capacity to Absorb Disturbance and Maintain Function; Island Press: Washington, DC, USA, 2012.

104. Lade, S.J.; Walker, B.H.; Haider, L.J. Resilience as pathway diversity: Linking systems, individual, and temporal perspectives on resilience. Ecol. Soc. 2020, 25. [CrossRef]

105. Leach, M.; Scoones, I.; Stirling, A. Governing epidemics in an age of complexity: Narratives, politics and pathways to sustainability. Glob. Environ. Chang. 2010, 20, 369-377. [CrossRef]

106. Walker, J.; Cooper, M. Genealogies of resilience: From systems ecology to the political economy of crisis adaptation. Secur. Dialogue 2011, 42, 143-160. [CrossRef]

107. Helfgott, A. Operationalising systemic resilience. Eur. J. Oper. Res. 2018, 268, 852-864. [CrossRef]

108. Owens, S. Learning across levels of governance: Expert advice and the adoption of carbon dioxide emissions reduction targets in the UK. Glob. Environ. Chang. 2010, 20, 394-401. [CrossRef]

109. Young, O.R. Institutional dynamics: Resilience, vulnerability and adaptation in environmental and resource regimes. Glob. Environ. Chang. 2010, 20, 378-385. [CrossRef]

110. Chandler, D.; Grove, K.; Wakefield, S. Resilience in the Anthropocene: Governance and Politics at the End of the World; Routledge: New York, NY, USA, 2020. 
111. Parsons, M.; Thoms, M.C. From academic to applied: Operationalising resilience in river systems. Geomorphology 2018, 305, 242-251. [CrossRef]

112. Connors, P.; McDonald, P. Transitioning communities: Community, participation and the Transition Town movement. Community Dev. J. 2010, 46, 558-572. [CrossRef]

113. Reckhow, S.; Downey, D.; Sapotichne, J. Governing Without Government: Nonprofit Governance in Detroit and Flint. SSRN Electron. J. 2018, 1078087419847531. [CrossRef]

114. Dunn, W.N. Public Policy Analysis: An Introduction; Person Education, Inc.: Upper Saddle River, NJ, USA, 2015.

115. Gaus, G. What Might Democratic Self-Governance in a Complex Social World Look like. San Diego L. Rev. 2019, 56, 967.

116. Morris, G.L.; FAN, J. Reservoir Sedimentation Handbook: Design and Management of Dams, Reservoirs, and Watersheds for Sustainable Use; McGraw Hill Professional: New York, NY, USA, 1998.

117. World Commission on Dams. Dams and Development: A New Framework for Decision-making: The Report of the World Commission on Dams; Earthscan Publications Ltd.: London, UK; Sterling, VA, USA, 2000.

118. Hermoso, V. Freshwater ecosystems could become the biggest losers of the Paris Agreement. Glob. Chang. Biol. 2017, 23, 3433-3436. [CrossRef]

119. Bratrich, C.; Truffer, B.; Jorde, K.; Markard, J.; Meier, W.; Peter, A.; Schneider, M.; Wehrli, B. Green hydropower: A new assessment procedure for river management. River Res. Appl. 2004, 20, 865-882. [CrossRef]

120. New, T.; Xie, Z. Impacts of large dams on riparian vegetation: Applying global experience to the case of China's Three Gorges Dam. Biodivers. Conserv. 2008, 17, 3149-3163. [CrossRef]

121. Wilmsen, B. Progress, problems, and prospects of dam-induced displacement and resettlement in China. China Inf. 2011, 25, 139-164. [CrossRef]

122. Opperman, J.J.H.; Angarita, J.R.H.; Chapin, P.B.E.; Geressu, R.; Grill, G.; Harou, J.; Hurford, A.; Kammen, D.; Kelman, R.; Martin, E.; et al. The Power of Rivers: A Business Case; Andrew, M., Ed.; The Nature Conservancy: Washington, DC, USA, 2017.

123. Chen, C.; Cheng, H.; Jia, J.; Wang, X.; Zhao, J. Use it or not: An agro-ecological perspective to flooded riparian land along the Three Gorges Reservoir. Sci. Total Environ. 2019, 650, 1062-1072. [CrossRef]

124. Wang, L.P.; Huang, H.T.; Shi, J.; Zhang, Y.K.; Zhang, P. Terrestrial Ecological Risk Assessment Model of Nuozhadu Reservoir. Appl. Mech. Mater. 2013, 448, 838-845. [CrossRef]

125. Rogers, S.; Xue, T. Resettlement and climate change vulnerability: Evidence from rural China. Glob. Environ. Chang. 2015, 35, 62-69. [CrossRef]

126. Nguyen, H.T.; Pham, T.H.; De Bruyn, L.L. Impact of Hydroelectric Dam Development and Resettlement on the Natural and Social Capital of Rural Livelihoods in Bo Hon Village in Central Vietnam. Sustainability 2017, 9, 1422. [CrossRef]

127. Chen, X.; Zhao, T.; Li, C.; Zheng, H. Economic cost-benefit analysis of a hydropower development project based on different stakeholders: A case study of Lancang River, China. Acta Ecol. Sin. 2017, 37, 4495-4504.

128. Xu, Y.; Li, H. Rural resetlement of Nuozhadu Hydropower Station. Water Power 2005, 31, $20-22$.

129. Zhang, R.; Li, Y.; Yin, T.; Xie, Q.-F. Environment impact assessment of Nuozhadu Hydropower Station. Water Power 2005, 31, 23-25.

130. Yunnan Department of Forestry. Nuozhadu Nature Reserve; Yunnan Technology Publishing House: Kunming, China, 2003.

131. Chinairn. Brief Introduction of the Biggest Hydropower Station in Yunnan; ULCEN: Jinan, China, 2012; Available online: http: / / cusdn.org.cn/news_detail.php?id=222326 (accessed on 2 April 2018).

132. Mao, J.; Liu, X.; Lu, J.; Yang, C.; Yuan, J.; Yan, R. Prediction and Countermeasures of Nuozhadu Hydropower Station. Environ. Sci. Surv. 2017, 36, 76-79.

133. Small, M.L. How to Conduct a Mixed Methods Study: Recent Trends in a Rapidly Growing Literature. In Annual Review of Sociology; Cook, K.S., Massey, D.S., Eds.; Annual Reviews: Palo Alto, CA, USA, 2011; Volume 37.

134. Song, L.; Li, H.; Li, S. Research on the Utilization and Evaluation of Library Resource Discovery Systems in China. Int. J. Libr. Inf. Serv. (IJLIS) 2020, 9, 17-50. [CrossRef]

135. Li, J.; Liu, Z.; Chen, R.; Hu, D.; Li, W.; Li, X.; Chen, X.; Huang, B.; Liao, L. The quality of reports of randomized clinical trials on traditional Chinese medicine treatments: A systematic review of articles indexed in the China National Knowledge Infrastructure database from 2005 to 2012. BMC Complementary Altern. Med. 2014, 14, 362. [CrossRef] [PubMed]

136. Denscombe, M. Communities of practice-A research paradigm for the mixed methods approach. J. Mix. Methods Res. 2008, 2, 270-283. [CrossRef]

137. Giersh, C. The Issue-Based Approach to Monitoring Political Risk; Global Risk Affairs; Berlin Risks's Research Institute: Berlin, Germany, 2011. Available online: https:/ / www.globalriskaffairs.com/2011/04/the-issue-based-approach-to-monitoring-politicalrisk/ (accessed on 19 August 2019).

138. Bazeley, P. Mixed methods in my bones": Transcending the qualitative-quantitative divide. Int. J. Mult. Res. Approaches 2018, 10, 334-341. [CrossRef]

139. Allen, C.R.; Birge, H.E.; Angeler, D.G.; Arnold, C.A.; Chaffin, B.C.; DeCaro, D.A.; Garmestani, A.S.; Gunderson, L. Quantifying uncertainty and trade-offs in resilience assessments. Ecol. Soc. 2018, 23, 23. [CrossRef]

140. Vaas, J.; Driessen, P.P.; Giezen, M.; Van Laerhoven, F.; Wassen, M.J. “Let me tell you your problems”. Using Q methodology to elicit latent problem perceptions about invasive alien species. Geoforum 2019, 99, 120-131. [CrossRef] 
141. Yu, Q.; Cao, S.; Hua, C. Inventory of vegetation at the flooded area after the construction of hydroelectric station in the Nuozhadu Nature Reserve. J. Nanjing For. Univ. (Nat. Sci. Ed.) 2004, 28, 80-82.

142. Lei, G.; Zheng, C. Conditions and development strategies of the Nuozhadu Nature Reserve. J. Heilongjiang Vocat. Inst. Ecol. Eng. 2014, 27, 11-13.

143. People's Government of Pu'er City. Notice of the People's Government of Pu'er City on Further Strengthening and Standardising the Resettlement Management of Hydropower Projects; People's Government of Pu'er City: Pu'er City, China, 2017.

144. People's Government of Si'mao District. Notice of the Establishment of the Leading Group for the Comprehensive Management of the Nuozhadu Reservoir Area; People's Government of Si'mao District: Pu'er City, China, 2018.

145. State Council. Regulation of the Implementation of the Forestry Law of People's Republic of China; The State Council of People's Republic of China: Beijing, China, 2005.

146. Proust, K.; Newell, B. Constructing Influence Diagrams \& Causal Loop Diagrams; The Australian National University: Canberra, Australia, 2020.

147. Walker, G. Environmental Justice: Concepts, Evidence and Politics; Routledge: New York, NY, USA, 2012.

148. Wesely, J. Environmental Justice and Urban Resilience in the Global South; Allen, A., Griffin, L., Johnson, C., Eds.; Palgrave MacMillan: New York, NY, USA, 2017; ISBN 978-1-137-47353-0.

149. Laterra, P.; Nahuelhual, L.; Vallejos, M.; Berrouet, L.; Pérez, E.A.; Enrico, L.; Jiménez-Sierra, C.; Mejía, K.; Meli, P.; Rincón-Ruíz, A.; et al. Linking inequalities and ecosystem services in Latin America. Ecosyst. Serv. 2019, 36, 100875. [CrossRef]

150. Wenta, J.; McDonald, J.; McGee, J.S. Enhancing Resilience and Justice in Climate Adaptation Laws. Transnatl. Environ. Law 2018, 8, 89-118. [CrossRef]

151. Allen, A.; Griffin, L.; Johnson, C. Environmental Justice and Urban Resilience in the Global South; Springer: New York, NY, USA, 2017.

152. Department for international Development. Sustainable Livelihoods Guidance Sheets; Department for international Development: London, UK, 1999.

153. Ellis, F.; Allison, E. Livelihood Diversification and Natural Resource Access; Overseas Development Group, University of East Anglia: Norwich, UK, 2004.

154. Poe, M.R.; McLain, R.J.; Emery, M.; Hurley, P.T. Urban Forest Justice and the Rights to Wild Foods, Medicines, and Materials in the City. Hum. Ecol. 2013, 41, 409-422. [CrossRef]

155. Skidelsky, E.; Skidelsky, R. How Much Is Enough? Money and the Good Life; Penguin Books: London, UK, 2012.

156. Cernea, M.M. For a new economics of resettlement: A sociological critique of the compensation principle. Int. Soc. Sci. J. 2003, 55, 37-45. [CrossRef]

157. Canagarajah, S. Reconstructing Local Knowledge. J. Lang. Identity Educ. 2002, 1, 243-259. [CrossRef]

158. Bond, A.; Palerm, J.; Haigh, P. Public participation in EIA of nuclear power plant decommissioning projects: A case study analysis. Environ. Impact Assess. Rev. 2004, 24, 617-641. [CrossRef]

159. Elling, B.; Nielsen, H.N. The misleading of public participation in environmental assessment-Exploring four infrastructure cases in Denmark. J. Environ. Policy Plan. 2017, 20, 282-297. [CrossRef]

160. Manorom, K.; Baird, I.G.; Shoemaker, B. The World Bank, Hydropower-based Poverty Alleviation and Indigenous Peoples: On-the-Ground Realities in the Xe Bang Fai River Basin of Laos. Forum Dev. Stud. 2017, 44, 275-300. [CrossRef]

161. Sellberg, M.M.; Ryan, P.; Borgström, S.T.; Norström, A.V.; Peterson, G.D. From resilience thinking to Resilience Planning: Lessons from practice. J. Environ. Manag. 2018, 217, 906-918. [CrossRef]

162. Hansen, M.H.; Li, H.; Svarverud, R. Ecological civilisation: Interpreting the Chinese past, projecting the global future. Glob. Environ. Chang. 2018, 53, 195-203. [CrossRef]

163. Peng, M.; Xu, H.; Qu, C.; Xu, J.; Chen, L.; Duan, L.; Hao, J. Understanding China's largest sustainability experiment: Atmospheric and climate governance in the Yangtze river economic belt as a lens. J. Clean. Prod. 2021, 290, 125760. [CrossRef]

164. Bai, H.; Wang, J. Guotian Liu and Jinsida Group Co., Ltd.-To Keep Lucid Waters and Lush Mountains for the Next Generation. In Entrepreneurship in the Asia-Pacific: Case Studies; Springer International Publishing: Singapore, 2019; pp. 71-91.

165. Lade, S.J.; Haider, L.J.; Engström, G.; Schlüter, M. Resilience offers escape from trapped thinking on poverty alleviation. Sci. Adv. 2017, 3, e1603043. [CrossRef] [PubMed]

166. Dai, L.; Liu, X.; Huang, X. Traditional Knowledge from Yuannan Ethnic Minorities on Agriculture and Biolodgy; China Science Publishing: Beijing, China, 2012.

167. Jinlong, L.; Renhua, Z.; Qiaoyun, Z. Traditional forest knowledge of the Yi people confronting policy reform and social changes in Yunnan province of China. For. Policy Econ. 2012, 22, 9-17. [CrossRef]

168. Du, F. Ecological Resettlement of Tibetan Herders in the Sanjiangyuan: A Case Study in Madoi County of Qinghai. Nomadic Peoples 2012, 16, 116-133. [CrossRef]

169. Biggs, R.; Schlüter, M.; Biggs, D.; Bohensky, E.L.; BurnSilver, S.B.; Cundill, G.; Dakos, V.; Daw, T.M.; Evans, L.S.; Kotschy, K.; et al Toward Principles for Enhancing the Resilience of Ecosystem Services. Annu. Rev. Environ. Resour. 2012, 37, 421-448. [CrossRef]

170. Webber, M.; McDonald, B. Involuntary Resettlement, Production and Income: Evidence from Xiaolangdi, PRC. World Dev. 2004, 32, 673-690. [CrossRef]

171. Yan, D.; Shi, G.; Yi, Q. The impacts of the dams construction on sustainable livelihoods and the re-construction method. Water Resour. Dev. Res. 2011, 6, 49-53. 
172. Yan, D.; Wang, M.; Wang, H.; Shi, G. Policy and implementation of land-based resettlement in China (1949-2014). Int. J. Water Resour. Dev. 2018, 34, 453-471. [CrossRef]

173. Brendan, A.G.; Mark, I.; Bryan, T. Dam-Induced Displacement and Agricultural Livelihoods in China's Mekong Basin. Hum. Ecol. 2013, 41, 437-446.

174. State Council. Regulation on Land Requisition Compensation and Resettlement of Resettlers for Large and Medium Hydropower and Hydroelectricity Projects; The State Council of People's Republic of China: Beijing, China, 2017.

175. Wilmsen, B. Is Land-based Resettlement Still Appropriate for Rural People in China? A Longitudinal Study of Displacement at the Three Gorges Dam. Dev. Chang. 2018, 49, 170-198. [CrossRef]

176. Huadong Engineering Corporation Limited. Investigation Report on Environmental Protection Acceptance of Completion of Gong Guo Qiao Hydropower Station in Lancang River, Yunnan Province; Huadong Engineering Corporation Limited: Hangzhou, China, 2015.

177. Ding, S. Investigating the Resettlement Practices in Ninxia Province with Aims of Ecology Protection and Poverty Alleviation: A Case Study of M Town. Ph.D. Thesis, Philosophy Lanzhou University, Lanzhou, China, 2015.

178. Knill, C.; Tosun, J. Public Policy: A New Introduction; Palgrave Macmillan: Basingstoke, UK; New York, NY, USA, 2012. 